\title{
PNL-2768
}

UC-71

\section{Assessment of Synfuel Transportation to Year 2000}

W. Wakamiya

K. B. Sebelien

M. A. Parkhurst

March 1979

Prepared for the U.S. Department of Energy under Contract EY-76-C-06-1830

Pacific Northwest Laboratory Operated for the U.S. Department of Energy by Battelle Memorial Institute 


\title{
NOTICE
}

This report was prepared as an account of work sponsored by the United States Government. Neither the United States nor the Department of Energy, nor any of their employees, nor any of their contractors, subcontractors, or their employees, makes any warranty, express or implied, or assumes any legal liability or responsibility for the accuracy, completeness or usefulness of any information, apparatus, product or process disclosed, or represents that its use would not infringe privately owned rights.

The views, opinions and conclusions contained in this report are those of the contractor and do not necessarily represent those of the United States Government or the United States Department of Energy.

\author{
PACIFIC NORTHWEST LABORATORY \\ operated by \\ BATTELLE \\ for the
}

UNITED STATES DEPARTMENT OF ENERGY

Under Contract EY-76-C-06-1830

\begin{tabular}{|c|c|}
\hline \multicolumn{2}{|c|}{$\begin{array}{l}\text { Printed in the United States of America } \\
\text { Available from } \\
\text { National Technical Information Service } \\
\text { United States Department of Commerce } \\
5285 \text { Port Royal Road } \\
\text { Springfield, Virginia } 22151\end{array}$} \\
\hline Price: Printed Copy & $\because$ Microfiche $\$ 3.00$ \\
\hline -Pages & $\begin{array}{c}\text { NTIS } \\
\text { Selling Price }\end{array}$ \\
\hline $001-025$ & $\$ 4.00$ \\
\hline $026-050$ & $\$ 4.50$ \\
\hline $051-075$ & $\$ 5.25$ \\
\hline $076-100$ & $\$ 6.00$ \\
\hline $101-125$ & $\$ 6.50$ \\
\hline $126-150$ & $\$ 7.25$ \\
\hline $151-175$ & $\$ 8.00$ \\
\hline $176-200$ & $\$ 9.00$ \\
\hline $201-225$ & $\$ 9.25$ \\
\hline $226-250$ & $\$ 9.50$ \\
\hline $251-275$ & $\$ 10.75$ \\
\hline $276-300$ & $\$ 11.00$ \\
\hline
\end{tabular}


PNL-2768

UC-71

33679000493140

ASSESSMENT OF SYNFUEL TRANSPORTATION

TO YEAR 2000

W. Wakamiya

K. B. Sebelien

M. A. Parkhurst

March 1979

Prepared for the U. S. Department of Energy Under Contract EY-76-C-06-1830

Pac ific Northwest Laboratory

Richland, Washington 99352 



\section{SUMMARY}

This report is directed to identifying and discussing potential problems in the transportation of synthetic fuels (synfuels) which if allowed to persist unresolved will hamper the development of these energy materials between now and the year 2000. For the purposes of this work, the scope of synfuels considered is narrowed to five specific materials: shale oil, synthetic gas from coal, coal syncrude, methanol from coal, and hydrogen. Consequently, for problems to be of concern, two criteria must be met: 1) the problem must be inherent in transportation of one of these five materials, and 2) the problem must be anticipated to surface prior to the year 2000. The latter point may be the controlling factor and necessitates a determination of when each synfuel is likely to be commercialized.

Despite growing pressure within the United States to reduce reliance on foreign fuels, achievement of that goal through commercialization of synfuels will not occur until these fuels can provide delivered energy output per unit cost competitive with that available from fossil fuels. It is currently projected that as a result of economic factors synfuels will not make a significant contribution to the national energy supply before 1990, and possibly not until the year 2000. Optimistic estimates suggest that the first two synfuels likely to be commercialized, shale oil and coal syncrudes, will account for approximately $7 \%$ and $9 \%$ of petroleum demand, respective $1 y$, by the end of the century.

The emergence of transportation-related problems in shale oil and coal synfuel development will be highly dependent upon their chemical similitude with analagous fossil fuels. Should the new fuels be sufficiently different to cause problems arising from incompatibility with packaging materials, new regulations, designs and equipment will be required for synfue 1 transportation. Should the fuels be essentially the same as current fossil fuels, transportation problems will be limited to those already identified for petroleum and natural gas. Hence, definitive resolution of the question of whether new transportation problems exist is dependent upon clear characterization of the synfuels chemical composition. Hydrogen and methanol 
represent unique cases since these materials are already in commercial production. The major transportation problem identified with fuel economics based on these materials is related to bulk use. To date, shipment volumes have been relatively small and, in the case of hydrogen, can be accommodated with costly, more specialized packaging. Scale-up for major energy use may introduce a new set of transportation problems. 


\section{ACKNOWLEDGMENTS}

This report is an account of effort in a task of the project "Energy Material Transport, Now through 2000, System Characteristics and Potential Problems." The project is sponsored by the Department of Energy, Division of Environmental Control Technology, Transportation Branch. The authors gratefully acknowledge the technical assistance provided by the many individuals identified in Appendix $B$ of this report, who supplied information during the course of this study. 


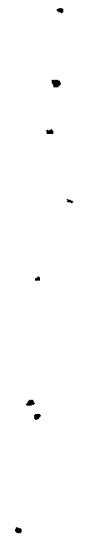




\section{CONTENTS}

SUMMARY

ACKNOWLEDGMENTS

LIST OF FIGURES

LIST OF TABLES

ABBREV IATIONS

INTRODUCTION

CONCLUSIONS

OVERVIEW OF SYNFUEL TECHNOLOGY

SHALE OIL

COAL CONVERSION SYNFUELS

HYDROGEN

PROJECTED PRODUCTION AND COST SCENARIOS

TRANSPORTATION LOGISTICS

PIPELINES

BARGES

RAILROADS

MOTOR CARRIER

SYNTHETIC FUEL TRANSPORTATION SUMMARY

POTENTIAL PROBLEM IDENTIFICATION, EVALUATION, AND RECOMMENDATIONS. • 41

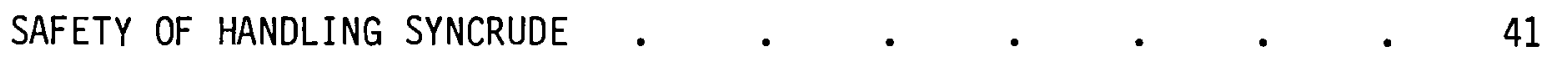

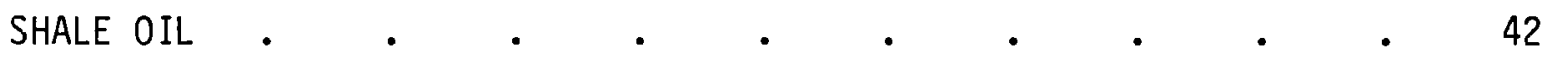

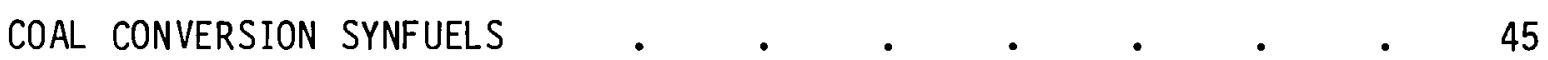

HYDROGEN

REFERENCES .

BIBLIOGRAPHY

APPENDIX A - STATUS AND OUTLOOK OF OIL SHALE DEVELOPMENT PROJECTS

APPENDIX B - TELEPHONE CONTACTS

APPENDIX C - REGULATIONS

APPENDIX D - HAZARDOUS MATERIAL SHIPPING REGULATIONS •

A-1

APPENDIX E - RECENT STUDIES ON HYDROGEN EMBRITTLEMENT

$B-1$

APPENDIX F - FEDERAL REGULATIONS ON BULK HYDROGEN TRANSPORT. 



\section{LIST OF FIGURES}

1 Graphical Presentation of Projected Energy Costs (Table 5) - Natural Gas and SNG $\quad \cdot \quad \cdot \quad \cdot \quad \cdot \quad \cdot 28$

2 Graphical Presentation of Projected Energy Costs (Table 5) - Crude and Syncrude . . . . . . 29

3 Graphical Presentation of Projected Estimates for Syncrudes and Synthetic Gas (Table 6) .

4 Potentially Available SNG Transportation - Pipelines . . . 34

5 Potentially Available Syncrude Transportation - Pipelines . . 35

6 Potentially Available Syncrude and Methanol Transportation Inland Waterway $\quad \cdot \quad \cdot \quad \cdot \quad \cdot \quad \cdot \quad \cdot \quad \cdot \quad \cdot 36$

7 Potentially Available Syncrude and Available Methanol

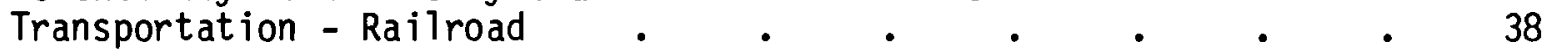

8 Hydrogen Transportation Scenarios • . • • • • 52

9 Liquid Hydrogen Losses During Transport, Transfer, and Storage . 


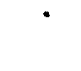




\section{$\underline{\text { LIST OF TABLES }}$}

1 Characteristics of Coal Gasification Technologies a . $\quad 12$

2 Coal Gasification Plant Projections . . . . . . . 13

3 Characteristics of Coal Liquefaction Technologies . $\quad . \quad$. 15

4 Synthetic Fuel Production Projections . . . . . . 24

5 Projected Costs of Fuels in 1975 Dollars . . . . . 25

6 Consolidated Production Estimates for Synfuels, Crude oil and Natural Gas . . . . . . . . . . 26

7 Synfuel Production/Conventional Fuel Demand Comparison. . . 27

8 Liquid Hydrogen Handling and Transfer Experience . • . 58

9 Relative Degree of Hydrogen-Environment Embrittlement 


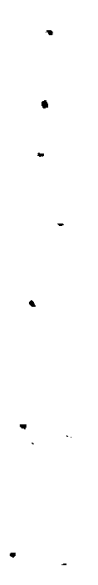




\title{
ABBREVIATIONS
}

\author{
AGA - American Gas Association \\ ANSI - American National Standards Institute \\ API - American Petroleum Institute \\ ARCO - At lantic Richfield Corporation \\ ASME - American Society of Mechanical Engineers \\ ASTM - American Society for Testing and Materials \\ ATC - Applied Technology Corporation \\ bb 1 - petroleum barre1, 42 U.S. gallons \\ $B / D$ - barrel per day \\ $B M$ - U.S. Bureau of Mines \\ CFR - Code of Federal Regulations \\ COE - crude oil equivalent \\ COED - Char-0il-Energy Deve lopment \\ CSF - Consol Synthetic Fuel \\ DOE - Department of Energy \\ DOT - Department of Transportation \\ EPA - Environmental Protection Agency \\ EPRI - Electric Power Research Institute \\ FRA - Federal Railroad Administration \\ FTFB - Ford Technical Fix Baseline \\ GATX - General American Transportation Corporation \\ ICC - Interstate Commerce Commission \\ IGT - Institute of Gas Technology \\ M - thousand \\ MM - million \\ MCI - Maximum Credible Imp lementation \\ MTB - Materials Transportation Bureau \\ NEE - Nuclear Electric Economy \\ NFPA - National Fire Protection Association \\ NPC - National Petroleum Council
}




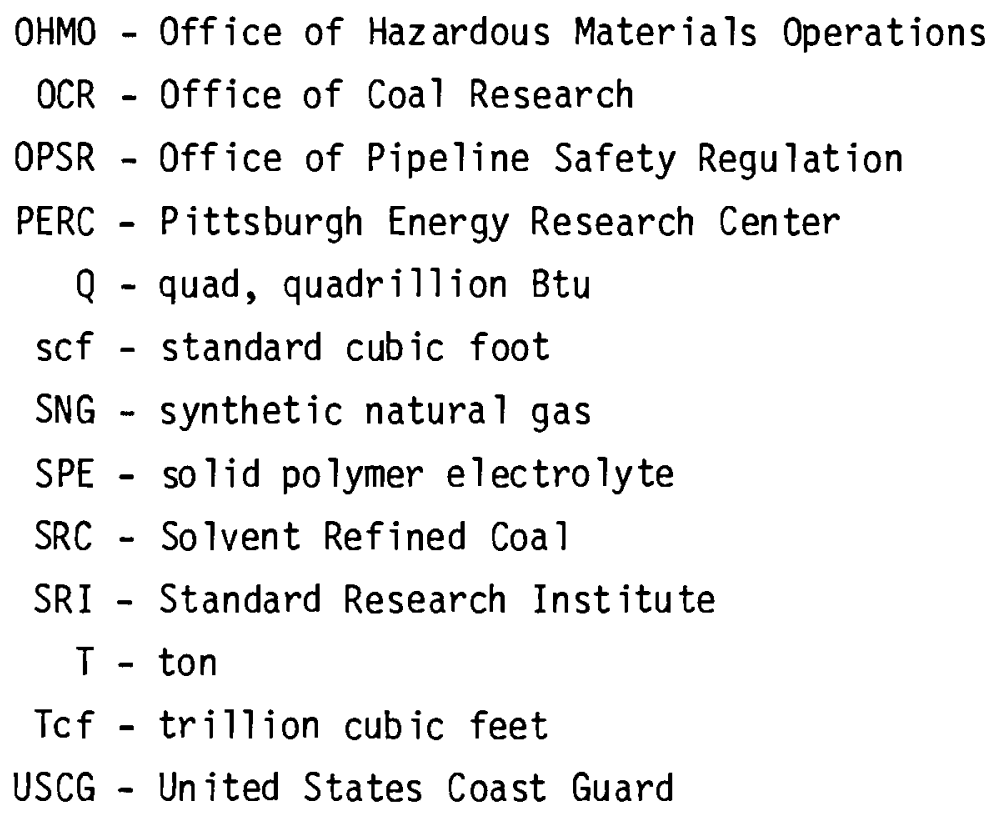




\section{INTRODUCTION}

Projections based on studies by government agencies and private institutions indicate that in the 1990s declining supplies of natural gas and petroleum will, at least in part, be augmented through the production of synthetic fuels (symfuels). Implic it in these projections is the assumption that current technical, environmental, and economic problems associated with commercialization have been resolved. Of the three, economic issues are the most crucial. Synthetic fuels will not appear in the marketplace to any extent until they can deliver a cost-to-energy-output ratio comparable to the ratios supplied by available fuels. The reality of this statement is most evident from analys is of two proposed synthetic fuels: methanol and hydrogen. Both commodities are commercially available today for other uses. Hence, the technology for commercialization is at hand; however, these materials do not compete economically with available fuels and therefore are not a significant factor in the current energy supply.

These same economic forces in the marketplace are likely to lead to the commercialization of synfuels near the turn of the century. Over time the dwindling supplies of natural gas and oil, the rising prices of foreign fuel imports, and the development of less costly means of producing synfuels will narrow the gap in cost per energy output until the synfuels become competitive.

In order to facilitate development of synfuels and assure that technical issues do not hamper commercialization, it is important to identify and evaluate all potential problems associated with synfuel production and use while ample time and resources are available for resolution. The overall objective of the work reported here in is to assess potential problems associated with the transportation of synfuels and other materials associated with synfuel commercialization. Because no synfuels are currently produced at a scale comparable with that anticipated after commercialization, the results of th is study are extrapolated from data and knowledge of current petroleum and gas transportation systems. Potential problem.areas are identified for further study. 
Synthetic fuels covered in this study are those that are most likely to be commercialized by the year 2000: shale 0il, liquefied coal, gasified coal, methanol, and hydrogen. Work was divided among four tasks to:

1. provide an overview of synfuel commercialization

2. evaluate the transportation network currently available to facilitate synfuel commercialization

3. identify the transportation network and considerations necessary to support commercialization

4. assess potential transportation problems which may impact the commercialization process.

This report presents the results obtained from conduct of these tasks. 


\section{CONCLUSIONS}

Technology is available for the production of synthetic fuels. Commercialization will depend upon advancement of that technology or changes in the marketplace which will satisfy current economic and environmental considerations. At this point, it appears that transportation will play a minor role in determining acceptability of synfuel production.

Synfuels (shale oil, coal conversion, and hydrogen) were considered in this study in terms of commercialization potential, transportation, and transportation regulations. The following major conclusions are drawn from this study.

SHALE OIL

- Although oil shale is abundant, commercial shale oil production is not likely to occur before 1985. Several environmental, economic, and governmental policies must be resolved in order to permit full-scale operation.

- Water availability is a major concern. Water is necessary for upgrading raw syncrude and for power generation. Further study is needed to determine the actual amount of water required for shale oil production.

- The mode or logistics of shale oil transportation will depend on the availability of water at a particular site. If the shale oil can be upgraded onsite, existing crude 011 pipelines may be used for distribution. If the shale oil must be upgraded offsite, alternate transportation methods may be required.

- While several agencies regulate the different facets of crude oil transportation, no regulations have been promulgated specifically for the distribution of synthetic crude.

COAL CONVERSION SYNFUELS

Processes for converting coal to gas or liquid fuels, although technically proven, are not commercially available in the United States. Several projects are now under way for further development of coal conversion methods. 


\section{Coal Gasification}

- The production of coal-derived gases is plagued with as-yet unresolved problems with sulfur removal and corrosion and erosion of process equipment. Some of these problems will be reduced if expansion of the coal industry, including coal conversion, is centered in the West, where the coal deposits have low sulfur concentrations.

- Synthetic natural gas (SNG) is considered the most viable product of gasification. SNG is basically pollutant-free, has similar characteristics to natural gas, and can be used by both industrial and residential consumers. Consequently, SNG can be transported through existing natural gas pipelines.

- Existing regulations for the transport of natural gas are considered to be adequate for future SNG transportation.

\section{Coal Liquefaction}

- Coal liquefaction is seen as a near-term alternative to replace decreasing supplies of petroleum and natural gas.

- Liquefaction has a greater energy conversion efficiency than gasification, and the liquid energy products (syncrude) can be substituted for liquid fue ls now used in transportation and home heating.

- Existing petroleum pipelines may be used to transport coal syncrude. Corrosion and compatibility problems with this synfuel in current techno logy equipment have yet to be identified. Should they arise, they would require the development of new refining and control techniques. Further assessments are needed to determine the compatibility of syncrude with materials used for petroleum transportation.

- Tank barges and railroad transport in unit tank car trains are likely modes of transportation for syncrudes assuming no problems with product compatibility.

- Regulatory requirements are likely to be the same as those for oil syncrude. 
Methanol from Coal

- Methanol is currently derived from petroleum and natural gas, and already has a number of uses. Methanol from coal may become competitive in the future as a substitute for or fuel additive to gasoline.

- Existing modes of transportation of methanol will continue. These modes include barges, railroads, and pipelines. The possibility of using unit tank trains is being explored.

- Regulatory authorities for coal-derived methanol are already well defined. Any changes anticipated will concern modes of bulk movement.

HYDROGEN

- Hydrogen is not expected to make a significant contribution to energy supplies before the year 2000. Wide-scale acceptance is hampered by public perception through identification of hydrogen with the Hindenburg incident and the hydrogen-bomb. Furthermore, although hydrogen is abundant, relatively nonpolluting, and efficient, its production requires energy from other fuels.

- While hydrogen has been used safely in the space industry, a widespread use may require additional controls and changes in current safety standards. Hydrogen has never been transported in the bulk quantities which would follow large-scale commercialization.

- Most existing regulations applicable to hydrogen transportation are general and apply to hazardous materials without specific reference to hydrogen or consideration of problems unique to hydrogen.

$\underline{\text { Gas }}$

- A11 current and proposed methods for production deal with gaseous hydrogen, rather than liquid or hydrides.

- Of the several methods for production of hydrogen gas, catalytic steam reforming is the most economical but this method uses petroleum feedstock. While others are more expensive, they may become attractive methods for extending hydrogen production capabilities and the use of hydrogen as an energy source. 
- In a mature, large-scale hydrogen economy, the best method of storage appears to consist of large natural underground reservoirs served by transmission pipelines.

- Existing natural gas pipelines may be adapted for hydrogen. However, a significantly increased compressor capacity would have to be provided and the possibility of pipeline and equipment embrittlement must be considered. Continued research and development is necessary in this problem area.

Liquid

- Liquid hydrogen has been used for many years in the space industry. Primary transportation has been provided by truck and rail, but other modes have also been employed.

- The major problem in the transport of liquid hydrogen is loss due to improper handling techniques, evaporation, and boil off.

Solid

- Solid hydrides are being considered as a method for storing hydrogen.

- Technical problems to be resolved relate to heat transfer, deterioration of the hydride bed material, embrittlement of the containers, and low energy density of storage.

- Concern has also been raised as to the safety of the hydride bed because of the pyrophoric properties of hydride particles. 
OVERVIEW OF SYNFUEL TECHNOLOGY

Since the Organization of Petroleum Exporting Countries (OPEC) embargo on petroleum, attention has been focused on ways to decrease U.S. dependence on foreign fuel stocks and increase self-sufficiency through development of synthetic fuels, especially coal conversion synfuels. Although no commercial venture is operating in the U.S. at this time, cormercial synfuel from plants in South Africa and Germany have mitigated fuel shortages in those countries. Many technologies exist for production of syncrude, synthetic gas, methano 1 and hydrogen, but commercial operations will not begin until production becomes more economical.

During June 1978, the Department of Energy (DOE) reviewed commercialization prospects for 16 major groups of energy projects. These projects included 23 different types of energy technologies, 10 of which were deemed "near-term marketing" and 13 of which were classified as facing technical, regulatory, or economic obstacles to commercialization of the technology (Department of Energy, 1978b). Gasification and liquefaction of coal and oil shale were in the group regarded as having significant obstacles to commercialization. Syncrude from oil shale technology was held to be more advanced and the closest to commercial application. Methanol and hydrogen, considered to be possible future fuels, were not included in the DOE review.

\section{SHALE OIL}

Two major oil shale deposits with in the United States are in the Green River formation of Colorado, Utah, and Wyoming, and Devonian-Mississippian black shale formation of Midwest and East. Current interest is directed toward the Green River formation because of its richer, thicker oil shale.

0il shale is the term applied to fine-grain sedimentary rocks which contain appreciable quantities of an organic material called kerogen. Shale oil is the liquid oil product of the pyrolysis of kerogen from oil shale. After partial refining, the up-graded liquid is called synthetic crude $0 i 1$ or syncrude. (a) Bradley (1931) reports that the organic material present in

(a) Syncrude can also be obtained from coal liquefaction. 
Green River formation oil shale probably consists of three fractions. The largest fraction is kerogen. A much smaller fraction consists of bitumen, an organic material which is soluble in organic solvents and which will also decompose on pyrolysis. A third and very small fraction is an inert substance that is not soluble or does not yield oil on pyrolysis.

There are about 20 companies that have resources and potential to engage in oil shale activities (see Appendix A). About half have planned commercial projects but with current economics, they are not willing to cormit themselves to major development. As a result, a Federal role seems essential. A commercialization plan for oil shale must reduce economic, technical, and environmental risk for at least the initial plants and establish incentives for long-term commercial operation.

The Department of Energy's oil shale commercialization task force (Department of Energy, 1978c) has researched the readiness of the technology and various market components. A key issue they identified is the level of environmental concern wich "will most likely control the ultimate size" of the industry. Another is the land policy, since about $80 \%$ of the oil shale reserves is on public lands administered by the Federal Government. The task force's analysis included technical, economic, and environmental readiness, and the results can be summarized as follows:

Technical Readiness. Surface retorting is technically ready for 10,000 ton/day commercial modules. In situ technology has not been tested near commercial scale; it requires 1:10 or more scale-up factor. The outlook for results of in situ retorting will be known within 1 to 4 years.

Economic/Market Readiness. Production costs remain uncertain since there have been no commercial sized units. Cost ranging from $\$ 15$ to $30 / \mathrm{bb} 1$ have been estimated varying with the technology. Shale oil's competition will be primarily with imported oil. Except for its high nitrogen and arsenic content, the shale oil product is analogous to petroleum. With contaminants removed, the result is a "premium quality refinery feedstock or clean-burning boiler fuel." 
The task force projects that in 1985 shale oil's cost will be competitive with the expected ranges for imported foreign oil, Alaskan crude oil, and natural gas, and significantly lower than tertiary recovery, tar sands, coal liquids, and high-Btu gas.

The principal market barrier is price according to the task force analysis. An additional barrier is the acceptability, including reliability of delivery, of a new product in an established market.

Environmental Readiness. Significant deterioration and non-attainment regulations will tend to limit the size of the industry in any one area and will affect the industry's rate of development. There are contradictory views on the ability to meet environmental standards. Some of the concerns are the uncertainty of yet-to-be-promulgated new source performance standards, surface and ground-water controls, occupational hazards, and possible carcinogen icity of shale oil product.

The readiness of shale oil depends much on the outcome of the environmental issues. Environmental concerns, not markets, will most likely control the ultimate size of the oil shale industry. The development of the oil shale industry will be highly sensitive to the government's attitude and policy. While resource is well established and the technology well enough developed to predict commercial projects during the next decade, large investments from industry will depend on not only being convinced of success, but also confidence that governmental policy would not undermine an otherwise successful venture.

\section{COAL CONVERSION SYNFUELS}

Coal, a natural energy-rich resource, is abundantly available in the United States; coal deposits are estimated at over three trillion tons (Currie and Brown, 1975). Coal is primarily used for power generation in power plants and as coke in the steel industry. Coking coal is exported worldwide to steel producers. Railroads and barges transport the majority of coal moved with in the U.S. Gasification and/or liquefaction of coal is desirable since most factories, industries, buildings, and homes have been built and equipped to use $0 i 1$ and/or gas, not solid fuels. Cleaner, more convenient and usable gas 
and liquid fuels can be provided by coal gasification and liquefaction processes. These processes transform coal from one fuel type to another but are still unavailable commercially in the U.S.

There are four distinct coal conversion techniques under active consideration. These include: 1) pyrolys is, where temperature is a major factor in determining the quantities of gases and liquids products; 2) solvation, where the degree of hydrogenation determines the quantities of solids and liquids derived from dissolved coa 1; 3) hydrogenation, where temperature and the presence or absence of a catalyst are major factors in determining quantities of gases and/or liquids produced with pressurized coal; and 4) oxidation in the presence of steam, where a synthes is gas is produced. Coal Gasification

Coal gasification processes result in the production of low- and intermediate-Btu gases as well as synthetic natural gas (SNG). A single good system for the production of low and intermediate Btu gases is still not available. Acceptable levels of conversion efficiency require resolution of problems with sulfur removal and corrosion and erosion of process equipment.

Intermediate-Btu gas (synthes is gas) undergoes methanation to produce SNG (high-Btu) gas. However, to date the methanation step has on ly been demonstrated in pilot plants; it has not been operated and proven on a commercial scale and remains expensive (Braunstein et al., 1977). Synthetic natural gas is basically pollutant-free at the point of use and would be advantageous to industrial and residential consumers. Few modifications would be required in existing natural gas pipelines or at the point of use because SNG has the correct heating value, pressure, composition, and combustion characteristics when substituted for pipeline grade natural gas (Comittee on Future Energy Prospects, 1977; American Gas Association, 1977b; Stanford Research Institute, 1977). Initial SNG production has been estimated to occur in the mid-1980s in the U.S. In 1975 it was reported that Lurgi-process SNG production would cost from $\$ 2.75$ to $3.20 / \mathrm{MMBtu}$. With a $4 \%$ inflation rate, the cost range could be as high as $\$ 8.53 /$ MMBtu by the year 2000 (Howard-Smith and Werner, 1976). 
Synthetic fuel gases produced from coal gasification have a heating value range of approximately 150 to 990 Btu per standard cubic foot (scf) and are compiled in Table 1. Coal gasification processes include: Lurgi, Koppers-Totzek and Winkler, Hygas, Bigas, Atgas, Hydrane, and Synthane. However, a major research and development effort is under way to provide more efficient and versatile coal gasification methods than the commercially proven processes, i.e., Lurgi, Koppers-Totzek (Committee on Future Energy Prospects, 1977). Announced coal gasification projects for production of SNG using the Lurgi process are sited in the States of Montana, New Mexico, North Dakota, and Wyoming, near coal deposits (Table 2).

Because Western coal deposits are low in sulfur concentration, utilization of these deposits would require less capital investment to comply with EPA emission standards. This is one reason why a large part of the coal industry expansion is expected in the West with a large energy conversion industry to be centered there (Hinkle and Foley, 1976). According to the American Gas Association (AGA), most gasification plants for SNG production will be located at the coal mine mouth with two or three located on pipelines and two or three plants requiring additional pipeline mileage ( $100 \mathrm{miles}$ or less) for feeder line connections.

\section{Coal Liquefaction}

Coal liquefaction processes are classified as the catalytic synthes is of hydrocarbons after production of synthes is gas, dissolution of coal with a minimum of hydrogenation, catalytic pressurized hydrogenation of coal with a hydrogen or hydrogen and carbon monoxide mixture, or a sequential (staged) pyrolys is of coal to remove the volatile matter.

While the technology for coal conversion into gaseous and liquid fuels has continued to advance, there still is no commercially proven process for large-scale coal liquefaction. Liquefaction of coal requires less hydrogenation than gasification, fewer chemical transformations, milder physical conditions, and use of proven conventional equipment. At the same time the energy conversion efficiency is greater. Coal liquefaction processes 
TABLE 1. Characteristics of Coal Gasification Technologies (Maritime Administration and U.S. Coast Guard, 1974; Rothberg, 1978a)

\begin{tabular}{|c|c|c|c|}
\hline Developer/Sponsor & Type/Process & Gas Kind & $\begin{array}{l}\text { Heating value } \\
\text { (Btu/SCF) } \\
\end{array}$ \\
\hline $\mathrm{IGT} / \mathrm{AGA}$ & U-Gas Process & Low Btu & 155 \\
\hline $\begin{array}{l}\text { McDowe 11-We } 11 \text { man/ } \\
\text { We } 11 \text { man-Galusha }\end{array}$ & Wellman-Galusha Gasifier & Low Btu & 168 \\
\hline PERC/OCR & Bi-Gas Process (air) $)^{(b)}$ & Low Btu & 175 \\
\hline$B M / A G A, O C R$ & Lurgi Process (air) & Low Btu & 185 \\
\hline Germany & Koppers-Totzek (a) & Intermediate Btu & $\begin{array}{c}300 \\
\text { (raw gas) }\end{array}$ \\
\hline ATC/ACA, EPA, OCR & PATGAS & Intermediate Btu & 315 \\
\hline PERC/OCR & Bi-Gas Process $\left(\mathrm{O}_{2}\right)^{(\mathrm{b})}$ & Intermediate Btu & 380 \\
\hline Consol/AGA, OCR & $\mathrm{CO}_{2}$ Acceptor $(\mathrm{D})$ & Intermediate Btu & 400 \\
\hline PERC /OCR & $\begin{array}{l}\text { Bi-Gas Proces } \$ \text { b) } \\
\text { (methanation) }\end{array}$ & High Btu & 900 \\
\hline PERC & Synthane Process(b) & High Btu & 927 \\
\hline ATC/AGA, EPA, OCR & ATGAS & High Btu & 940 \\
\hline PERC/BM & Hydrane Process & High Btu & 954 \\
\hline $\begin{array}{l}\text { Davy Powergas, } \\
\text { Inc. }\end{array}$ & Wink ler (a) & High Btu & 960 \\
\hline IGT/AGA & Hygas Process & High Btu & 970 \\
\hline Germany & Lurgi Process $\left(\mathrm{O}_{2}\right)$ & High Btu & 979 \\
\hline
\end{tabular}

(a) Cormercial processes which have been considered for SNG production.

(b) Newer, more advanced processes.

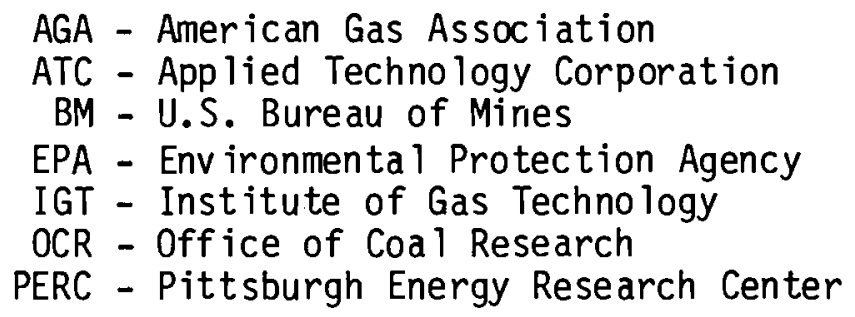




\section{TABLE 2. Coal Gasification Plant Projections}

\begin{tabular}{|c|c|c|c|}
\hline $\begin{array}{l}\text { Name of Process/ } \\
\text { State of Location }\end{array}$ & $\begin{array}{l}\text { Number of Plants/ } \\
\text { Output per Plant }\end{array}$ & Data Available & References \\
\hline Lurgi/New Mexico & $1 \mathrm{plant} / 288 \mathrm{MCF} / \mathrm{D}$ & & Committee on Future \\
\hline Lurgi/New Mexico & $\begin{array}{l}1 \mathrm{plant} / 250 \mathrm{MCF} / D \text { expansion } \\
\text { to } 3 \text { plants } 250 \mathrm{MCF} / 0 \text { each }\end{array}$ & & 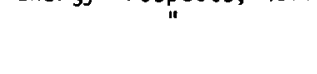 \\
\hline Lurgi/North Dakota & $1 \mathrm{plant} / 250 \mathrm{MCF} / \mathrm{D}$ & $\begin{array}{l}\text { Build in two phases } \\
\text { - Phase } 1 \text { operational by } 1982 \\
\text { - Phase } 2 \text { initiated in 1981-1982 }\end{array}$ & $"$ \\
\hline Lurgi/North Dakota & $\begin{array}{l}1 \mathrm{plant} / 250 \mathrm{MCF} / 0 \text { expansion } \\
\text { to } 3 \text { plants } 250 \mathrm{MCF} / 0 \text { each }\end{array}$ & First plant operational in 1982 & $"$ \\
\hline Lurgi/Wyoming & $1 \mathrm{plant} / 250 \mathrm{MCF} / \mathrm{D}$ & $1982-1994$ & $"$ \\
\hline Lurgi/Montana & $\begin{array}{l}1 \mathrm{plant} / 250 \mathrm{MCF} / \mathrm{D} \text { expansion } \\
\text { to } 2 \text { plants } 250 \mathrm{MCF} / \mathrm{D} \text { each }\end{array}$ & & $"$ \\
\hline Lurgi/lllinois & & & $"$ \\
\hline $\begin{array}{l}\text { Lurgi SNG from } \\
\text { LS/LBtu Coal }\end{array}$ & $250 \mathrm{MCF} / \mathrm{D}$ & 1990 & $\begin{array}{l}\text { Stanford Research } \\
\text { Institute, } 1977\end{array}$ \\
\hline $\begin{array}{l}\text { Lurgi SNG from } \\
\text { HS/HBtu Coal }\end{array}$ & $250 \mathrm{MCF} / \mathrm{D}$ & 1990 & " \\
\hline $\begin{array}{l}\text { Advanced SNG from } \\
\text { LS/LBtu Coal }\end{array}$ & $250 \mathrm{MCF} / \mathrm{D}$ & 1992 & $"$ \\
\hline $\begin{array}{l}\text { Advanced SNG from } \\
\text { HS/HBtu Coal }\end{array}$ & $250 \mathrm{MCF} / \mathrm{D}$ & 1992 & $"$ \\
\hline $\begin{array}{l}\text { Lurgi Low Btu Gas } \\
\text { from LS/LBtu Coal }\end{array}$ & $750 \mathrm{MCF} / \mathrm{D}$ & 1990 & $"$ \\
\hline $\begin{array}{l}\text { Lurgi Low Btu Gas } \\
\text { from HS/HBtu Coal }\end{array}$ & $750 \mathrm{MCF} / \mathrm{D}$ & 1990 & $"$ \\
\hline $\begin{array}{l}\text { Advanced Low Btu Gas } \\
\text { from LS/LBtu Coal }\end{array}$ & $1030 \mathrm{MCF} / \mathrm{D}$ & 1992 & $"$ \\
\hline $\begin{array}{l}\text { Advanced Low Btu Gas } \\
\text { from HS/HBtu Coal }\end{array}$ & $1030 \mathrm{MCF} / \mathrm{D}$ & 1992 & $"$ \\
\hline Lurgi/New Mexico & $\begin{array}{l}1 \mathrm{plant} / 250 \mathrm{MCF} / D \text { expansion } \\
\text { to } 2 \text { plants }\end{array}$ & $\begin{array}{l}\text { Construction pending financing } \\
\text { and site lease }\end{array}$ & $\begin{array}{l}\text { American Gas } \\
\text { Association, 1977a }\end{array}$ \\
\hline Lurgi/New Mexico & $1 \mathrm{plant} / 288 \mathrm{MCF} / \mathrm{D}$ & Requested FPC decision deferral & $"$ \\
\hline Lurgi/North Dakota & $1 \mathrm{plant} / 275 \mathrm{MCF} / \mathrm{D}$ & Start-up by late 1980s & $"$ \\
\hline Lurgi/North Dakota & $\begin{array}{l}1 \text { train/137 MCF } / D \text { expansion } \\
\text { to } 2 \text { trains }\end{array}$ & $\begin{array}{l}\text { Completion of full project } \\
(250 \mathrm{MCF} / \mathrm{D}) \text { expected in } 1930 \text { 's }\end{array}$ & $"$ \\
\hline Lurgi/Wyoming & $1 \mathrm{plant} / 270 \mathrm{MCF} / \mathrm{D}$ & Operations begin in early 1980's & $"$ \\
\hline
\end{tabular}


which provide liquid energy products could help to fill the role played by liquid fuels in the U.S. economy for which no energy substitutes are presently available, such as transportation and home heating.

As domestic petroleum and natural gas supplies decrease, coal liquefaction is seen as one of the few alternatives available in the near term for liquid fuels. Epperly and Siegel (Braunstein et al., 1977) estimated that it would take approximately 5 years for the design, construction, and operation of a coal liquefaction pilot plant and a possible additional 4 years for the design and construction of a commercial size plant. Economics remains the key to commercialization. Based on current economic and technical trends, coalderived syncrude should become economically competitive by the year 2000 .

Liquefaction processes, indicated in Table 3, include the only commercially available process, the Sasol-Fisher-Tropsch and the Coal-0il-Gas (COG) refining, Char-0il-Energy Development (COED), Solvent Refined Coal (SRC), Consol Synthetic Fuel (CSF), H-Coal, TOSCOAL, Synthoil, and others. With the support of utilities, the Electric Power Research Institute (EPRI) recommended an accelerated program for commercialization of coal liquefaction processes by the Department of Energy (1978a,d). A contract for a design study has been awarded (July 1978) to Gulf 0il for its Solvent Refined Coal liquefaction process (SRC-II). Anticipated completion of a module for the SRC-II is 1982 with an operational commercial plant by 1987.

Although the liquid produced from each liquefaction process is similar, the properties differ. Subsequent refining yields products with properties more similar to current petroleum-derived fuels (Comittee on Future Energy Prospects, 1977). With minor revisions to a conventional refinery, syncrude from coal can be refined to the current array of refined petroleum products. The products enter the product distribution network commingled with other refined products (Hinkle and Foley, 1976). Syncrude economics include costs necessary to produce refinery feedstocks equivalent to those from sweet domestic crude oil (Stanford Research Institute, 1977). Conventional jet and diesel fuels are more difficult to produce because of the high aromaticity of the derived liquids; therefore, production is relatively more expensive (Committee on Future Energy. Prospects, 1977). 
TABLE 3. Characteristics of Coal Liquefaction Technologies (Rothberg, 1978a)

\begin{tabular}{|c|c|c|c|}
\hline Developer/Sponsor & Process & Type of Process & $\begin{array}{l}\text { Heating Value } \\
\text { of } 0 i 1(B t u / 1 b)\end{array}$ \\
\hline PERC/BM & Synthoi 1 & Hydrogenation & 17,700 \\
\hline $\begin{array}{l}\text { Hydroc arbon Research, Inc. } \\
\text { OCR, ARCO, EPRI }\end{array}$ & $\mathrm{H}-\mathrm{Coa} 1$ & Hydrogenation & \\
\hline $\begin{array}{l}\text { Pittsburgh and Midway Coa } 1 \\
\text { Mining Co. } / 0 \mathrm{CR}\end{array}$ & SRC & Hydrogenation & \\
\hline $\begin{array}{l}\text { Consolidation Coal Co. } / 0 \mathrm{CR} \text {, } \\
\text { American Electric Power Co. }\end{array}$ & CSF & Hydrogenation & \\
\hline FMC Corporation/OCR, EPRI & COED & Pyrolys is & \\
\hline Tosco/0il Shale Corp. & TOSCOAL & Pyrolysis & 16,000 \\
\hline Germany & $\begin{array}{l}\text { Fisher-Tropsch } \\
\text { Synthes is }\end{array}$ & $\begin{array}{l}\text { Catalytic } \\
\text { Conversion }\end{array}$ & \\
\hline
\end{tabular}

ARCO - At lantic Richfield Company

EPRI - Electric Power Research Institute

BM - U.S. Bureau of Mines

OCR - Office of Coal Research

PERC - Pittsburgh Energy Research Center

SRC - Solvent Refined Coa 1

CSF - Consol Synthetic Fue 1

COED - Char-0il-Energy Deve lopment

Methanol from Coal

Methanol is currently under consideration as a fuel additive or substitute for gasoline. It can be derived from coal and biomass or produced by coal gasification. In the U.S., essentially all methanol is currently produced by catalytic steam reforming of natural gas or light hydrocarbon feedstock (Corneil et al., 1977). The synthane gasification process is currently under investigation for the production of methanol. A gasoline-from-coal (Fisher-Tropsch synthesis) p.lant has been operated commercially by SASOL for more than 20 years in South Africa (Schiefelbein et al., 1977). 
The major potential use for methanol is as an additive, but a number of problems must be resolved before methanol can serve as an alternative or substitute fuel. Methanol use as automobile fuel may have some problems such as difficulties with cold engine startup, gasoline-methanol phase separation, and methanol incompatibility with certain fuel tank plating compounds. Other studies have shown that methanol could displace natural gas and fuel oil as a utility and industrial boiler fuel. The displaced fuel oil could become a source of gasoline.

An issue that will require resolution in the future is whether or not gasoline-type fuel will continue to be a major fuel in transportation systems. A gasoline-methanol mixture (up to $15 \%$ ) may prove to be a suitable substitute and cause the market for methanol to develop (Warren, 1976). The technology for coal-to-methanol production is currently available and is less capital intensive than coal-to-petroleum technology. If the gasoline-type fuels persist, attention must center on coal-to-petroleum and methanol conversion to gasoline processes. Although coal-to-methanol technology exists, large-scale plants utilizing it are only in the planning stage. Mobile 0il Corporation has developed a methanol conversion process which uses a proprietary catalyst to produce gasoline (Warren, 1976; Coughlin, 1978).

Methanol could satisfy the near-term demand as a gasoline extender, and later become a major chemical and fuel feedstock (Warren, 1976). Because SNG production from methanol technology already exists and methanol can be easily stored, the methanol-to-SNG production could supplement the natural gas supply at high demand periods (Warren, 1976).

Methanol from coal is not expected to be competitive with methanol-from0 il for at least another 20 years (Johnson, 1978a,b). Steam reforming may be the least costly methanol process in 1980. By the year 2000, methanol production from a coal conversion process may be less costly than steam reforming. 
HYDROGEN

Hydrogen is a possible medium for future energy transmission and storage but unlikely to contribute significantly to the national energy supply before 2000. It may be extracted from fossil fuels, from water, or from both simultaneously. While fossil fuel supplies are diminishing and must be considered as a limited resource, water can be considered inexhaustible. The advantages of hydrogen as a fuel include the environmental gains of low pollution from its combustion and the universal availability of the source material. Additional advantage of increased efficiency is frequently experienced in the internal combustion engines using hydrogen (Edeskuty 1978). A major disadvantage is that hydrogen does not exist naturally in its elemental form. Thus, energy is required to extract hydrogen from foss $i 1$ supplies or from water. This energy can be obtained directly from fossil fuels, but primary energy sources such as nuclear, solar, wind, fossil, geothermal, or ocean temperature gradient must be used to obtain hydrogen from water. This results in a net energy loss and can possibly lead to further environmenta 1 degradation.

Large quantities of hydrogen are produced today, mainly as a chemical intermediate for use in the chemical process industries. Little hydrogen is used as an energy source. The largest single use is as rocket fuel in the aerospace industry and at government laboratories and test sites.

Of the hydrogen produced and consumed in the U.S., "captive" hydrogen is the greater share compared to "merchant" hydrogen. Merchant hydrogen is gas produced by suppliers and shipped to the end users. Captive hydrogen is produced on site by users in the chemical and refining industries. Since captive hydrogen is not purchased on the open market, its use and growth trends are not as we 11 documented as those of merchant hydrogen. At present, between 1 and $7 \%$ of the hydrogen produced is delivered to users as "merchant" hydrogen (Kelley, 1975; Edeskuty, 1978). The balance is produced and used within a process system as captive hydrogen. At some future time, a shift in the ratio of captive to merchant hydrogen can be expected to take place. The timing and degree of transition to a large-scale merchant.hydrogen system will depend on 
such factors as producer-user geographical distribution patterns, size of the total hydrogen market, and the availability of large quantities of nonfossil hydrogen.

\section{Gaseous Hydrogen}

Catalytic steam reforming of natural gas or any other light hydrocarbon is the most economical method of production for hydrogen. Its cost advantage is expected to continue throughout the 1980s and 1990s. Its obvious disadvantage is its dependence on petroleum feedstocks, though its use for petroleum refining is not likely to be replaced by hydrogen generated from nonpetroleum sources.

When hydrogen is produced by catalytic steam reforming, methane or another light hydrocarbon is reacted with steam in the presence of a nickel catalyst. While any vaporizable light hydrocarbon may be used as feedstock, methane, with the highest hydrogen to carbon ratio of $4: 1$, is the most desirable. Some of the feedstock is used to heat the furnace, resulting in the loss of overall efficiency. The hydrogen produced is half from methane and half from the steam.

Catalytic steam reforming produces the major ity of hydrogen needs. It presently provides most of the hydrogen for ammonia, methanol, and for petroleum refining. It is expected to continue to lead market production into the year 2000. However, as the petroleum feedstocks dwindle and other processes become more economical, the use of coal gasification and electrolysis will increase.

Resid partial oxidation is another process for producing hydrogen. The resid feedstock is a heavy black oil residue which cannot be vaporized. It may be treated either by increasing the hydrogen concentration or by removing the carbon by coking which will effectively produce a lighter hydrocarbon. For hydrogen production, a gasification reactor is used to react the resid with steam and oxygen to produce hydrogen. The investment cost for this process is about double that of reforming.

Pressurized coal gasification, a process still in the research and development and pilot plant stage, offers an opportunity to produce hydrogen from the more prevalent coal rather than relying on petroleum production. It 
is considerably more expensive now and with construction costs on the rise, is expected to remain uncompetitive with steam reforming. Investment costs are three to four times that of steam reforming. Yet, it appears a viable way to extend hydrogen production capabilities. Operating costs are elevated due to handling of solid coal and transportation charges. High sulfur coal, environmentally undesirable for most uses, would be the optimal feedstock here. Less expensive than low sulfur coal, its sulfur content would have little effect on manuf acturing costs.

The Koppers-Totzek method of coal gasification is presently in commercial use outside the U.S. Hydrogen produced in this manner is used in ammonia manufacture. Design improvements of present coal gasification technology are actively being explored to reduce investment costs of the process. Commercial U.S. plants are expected on-line around 1982 or 1983. This process will become more attractive as natural gas and light hydrocarbon feedstocks become increasingly expensive.

Electrolysis, a method of producing high purity hydrogen, is a very costly process and operating expenses are directly affected by the cost of electricity. It may use coal, oil, solar, or nuclear energy as its energy source, and has an overall thermal efficiency of 30\% to $40 \%$, much less than that of $61 \%$ to $70 \%$ by reforming or coal gasification. The reaction makes use of anode and cathode and an electrolyte solution, usually potassium hydroxide, to split water into hydrogen and oxygen. This reaction requires a large amount of electricity. A new procedure replacing the potassium hydroxide with a solid polymer electrolyte (SPE) is under development and shows potential for reducing operating costs. Further improvements in plant design may increase thermal efficiency. Small hydrogen users may find electrolytically produced hydrogen an attractive source if they are located a long distance from a steam reformer.

Future hydrogen developments show possibilities of hydrogen produced by several thermochemical reaction pathways using heat and water. Photoproduction via microbial and biochemical processes may also be developed into possible pathways. Thermochemical production uses nuclear or solar energy as 
its heat source and produces hydrogen directly at a theoretical efficiency of $50 \%$ with no electrical intermediates. Lead time on this industry is 20 years and production is not expected before the year 2000. Hydrogen production driven by light reactions is in an early research and development stage and is too far in the future to be significant to this study.

\section{Liquid Hydrogen}

The first large-scale liquefaction plant in the U.S. for hydrogen was constructed in 1952. This plant was constructed at the National Bureau of Standards Cryogen ic Engineering Laboratory in Boulder, Colorado, and could produce about 0.5 ton/day ( $450 \mathrm{~kg} /$ day) of liquid para-hydrogen. The output from this plant was used primarily in a program to develop materials, equipment, and procedures for safe handling and storing of liquid hydrogen.

The liquefaction process for hydrogen is somewhat more complicated than for most other common gases. Unlike other common gases, high-pressure hydrogen gas will get warmer if allowed to expand at room temperature. For this reason, liquid nitrogen precoolers are usually used and the liquefaction of nitrogen is a part of the hydrogen liquefier. Added to this complication is the "ortho-para problem" of hydrogen. The difference between ortho-hydrogen and para-hydrogen isomers is that the electrons have an opposite spin direction. At room temperature gaseous hydrogen is $75 \%$ ortho and $25 \%$ para, while the equilibrium liquid is nearly pure para. The latent heat of conversion from ortho to para is greater than the latent heat of vaporization so that the conversion must be accomplished in the liquefier where this heat may be removed if the liquid is to be stored. The theoretical work of liquefaction of hydrogen is $5,002 \mathrm{Btu} / \mathrm{lb}\left(1.16 \times 10^{7} \mathrm{~J} / \mathrm{kg}\right)$ but it appears that there are rather severe practical limitations to approaching this value. Achieving a figure of merit greater than about one-third will not be feasible for hydrogen in a commercial plant. Therefore, the work required for liquefaction is taken as $15,000 \mathrm{Btu} / \mathrm{lb}\left(34.9 \times 10^{6} \mathrm{~J} / \mathrm{kg}\right)$. This includes conversion to the para state. 
Solid Hydrides

Metal hydrides have been proposed by two groups of investigators as a method of storing hydrogen: 1) at Brookhaven National Laboratories and 2) at the Phillips Laboratory in the Netherlands. Hydrides are metal-hydrogen compounds that have certain attributes that make them advantageous for storage of hydrogen. Unfortunately, there are also deficiencies that make hydrides unsuitable for certain types of hydrogen storage systems.

The hydride storage system operates in the following manner. Hydrogen under pressure is pumped into a container filled with a suitable metal or alloy which absorbs hydrogen and ultimately forms a metal hydride compounds. Since all of the useful metal-hydrogen compounds for storage are exothermic, the formation of the metal hydride is accomplished by the release of the heat of formation. This heat must be removed from the system or the hydride forming reaction will stop and hydrogen will no longer be stored. Each of the metal hydride systems will adsorb hydrogen up to an equilibrium pressure called the dissociation pressure. The dissociation pressure depends mainly on the temperature and the nature of the metal. When the hydride is reheated, the hydrogen gas is produced and the pressure inside the container increases to the equlibrium. If the hydrogen gas is removed from the system the pressure drops and more hydride dissociates. For conven ience of operation of a hydride system, these dissociation pressures and temperature should be close to atmospheric conditions.

Aside from considerations of heat of formation and pressures and temperatures involved in hydriding and dehydriding, it is desirable to have a low weight storage system, especially for a transportation application. Similarly, high density of storage is desirable so that a given weight of metal or alloy absorbs as much hydrogen as possible. The intermetallic compound, iron titanium hydride $\left(\mathrm{FeTiH}_{1.5}\right)$, has reasonably low heat of formation and dissociation pressures and temperatures close to atmospheric conditions, but this hydride provides only about $1.4 \%$ by weight of useful hydrogen (Cole et al., 1975). This percentage is further lessened by the weight of containers, heat 
exchangers, etc. Magnesium nickel hydride $\left(\mathrm{Mg}_{2} \mathrm{NiH}_{4}\right)$ is capable of storing an equivalent amount of hydrogen in half the weight. However, the $\mathrm{Mg}_{2} \mathrm{NiH}_{4}$ system operates at temperatures and pressures much higher than the $\mathrm{FeTiH}_{1.5}$ system. Consequently, these lighter hydrides have the drawback of higher heat of formation and higher operating temperatures and pressures. 


\section{PROJECTED PRODUCTION AND COST SCENARIOS}

Several references in the literature provide future production and cost projections for synthetic gas and synthetic crude oil. Production forecasts and cost projections from studies made by government agencies, industries, and private institutions have been compiled in Tables 4 , and 5 . Figures 1 and 2 are graphical presentations of Table 5. Table 6 contains consolidated estimates of synfuels, petroleum crude and natural gas production for the U.S. between 1985 and 2000 using averaged projections for the years 1985, 1990, and 2000; and single projections for 1995. Figure 3 illustrates the data in Table 6. Table 7 shows the comparison between synfuel production and conventional fue 1 demand.

Specific assumptions employed in Table 4 projections are as follows:

Exxon Company USA - Projection assumes the availability of capital funds, delay in the need for full attainment of a ir quality standards, long-term growth toward full employment, higher energy costs, and the availability of oil imports.

She $110 i 1$ Company - Assumptions for projections include: 1) environmental concerns prevent optimal development of a 11 forms of energy, 2) capital formation problems constrain energy development, and 3) wor ld oil demands strain the export limits of the oil producing countries in the latter 1980s.

Bureau of Mines - The on ly assumption used in the BM energy forecast is a continuation of existing patterns of resource utilization.

National Petroleum Council - The projections are based on these assumptions: 1) Federal support provides capital investments for various synfue 1 processes; 2) regulatory delays are avoided; 3 ) continuing $R$ and D programs in large pilot plants solve major technical problems associated with the synfuel processes; and 4) a worldwide crude oil supply will decline beginning in the early 1990s. 
Stanford Research Institute - Maximum Credible Implementation - This scenario examined a maximum impact situation to highlight both beneficial and adverse consequences of a synthetic fuel industry. Assumptions included in the scenario are: 1) all fuel conversion activities occur close to the mines; 2) an economic incentive is provided so the industry can develop; and 3 ) a continuing incentive allows deployment of the technology.

Jet Propulsion Laboratory - This projection is the combination of the Ford Technical Fix Baseline (FTFB), which anticipated heavy use of oil and gas as the energy sources, and the Nuclear Electric Economy (NEE) projection which relies more on the use of nuclear power and coal.

SRI International - Projection is a base case assumption wherein synfuels production is virtually zero in 1990. The methanol from coal is noncompetitive with other liquid and gaseous fuels under this assumption. Consequently, the production is low.

Exxon Research and Engineering Company - Projection is based on a study by Chem Systems, Inc., and has taken a potentially large escalation of construction costs into consideration. This projection does not include markets for the synthetic fuels production and transportation fuels on ly current chemical uses.

The methanol projection assumes natural gas and light hydrocarbon feedstocks become more expensive relative to coal, an improved coal conversion process for methanol production will be commercially available and the conversion process will be more economical than steam reforming by the year 2000 .

Cost projections compiled in Table 5 and graphed in Figures 1 and 2 indicate how competitive synthetic fuels are with price ranges for natural gas and crude oil. Synthetic natural gas (SNG) produced from Interior and Great Plains coal feedstocks may become competitive after 1995 with the price range projected for natural gas. Projected SNG price ranges are still higher than the free-market (deregulation) and low productivity price range for natural 


\section{TABLE 4. Synthetic Fuel Production Projections (barrels per day)(a)}

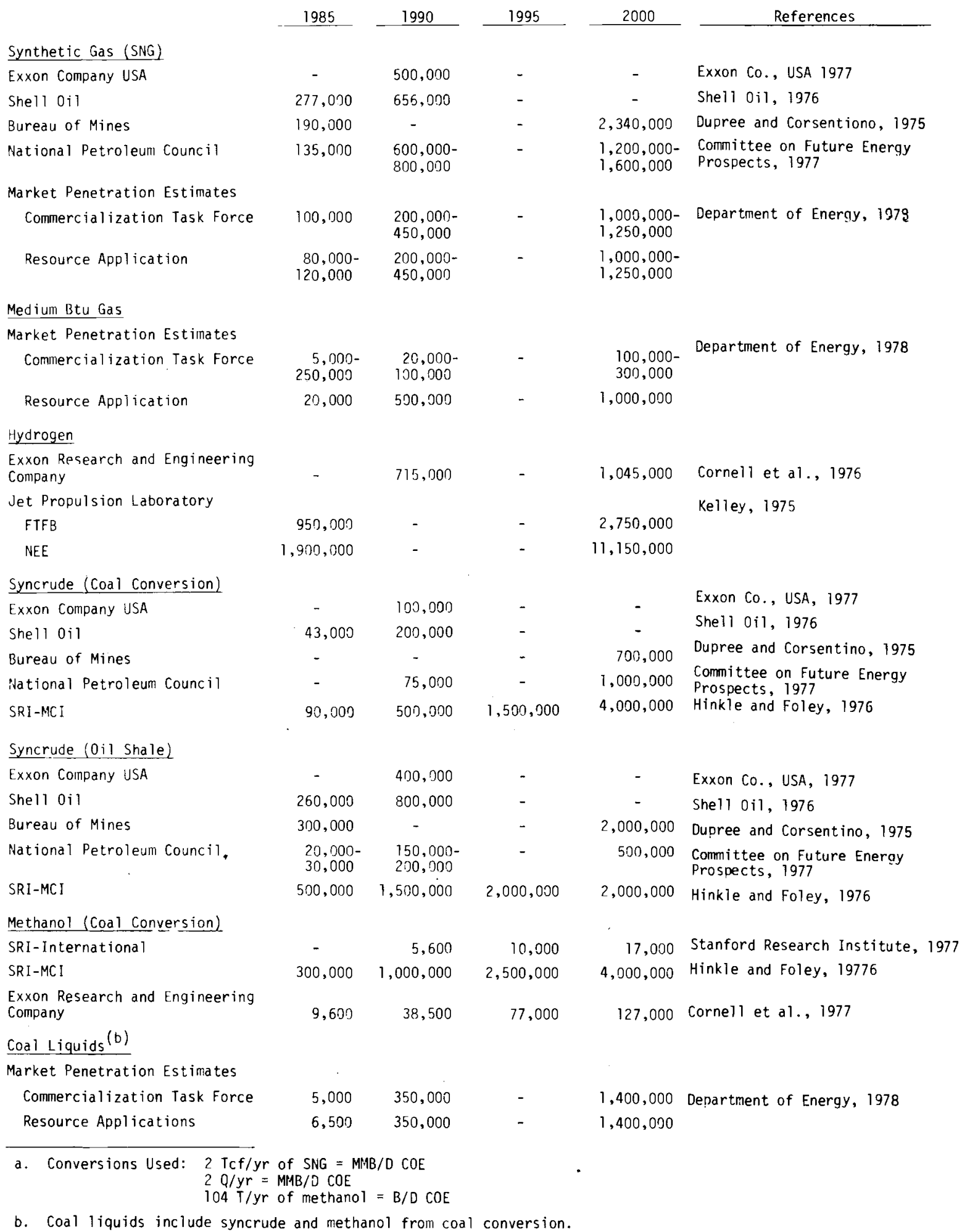




\section{TABLE 5. Projected Costs of Fuels in 1975 Dollars ( $\$ / \mathrm{mmBtu})$}

\begin{tabular}{|c|c|c|c|c|c|}
\hline \multirow{2}{*}{ Natural Gas } & 1985 & 1990 & 1995 & \multirow[t]{2}{*}{2000} & \multirow[t]{2}{*}{ References } \\
\hline & & & & & \\
\hline Low Productivity (a) & 2.02 & 2.21 & 2.34 & 2.46 & Foster Assoc. Inc., 1977 \\
\hline High Productivity (a) & 1.51 & 1.67 & 1.74 & 1.84 & Foster Assoc. Inc., 1977 \\
\hline Price Regulation (b) & 1.19 & 1.53 & 1.83 & 2.02 & Foster Assoc. Inc., 1977 \\
\hline Free Market ${ }^{(b)}$ & 2.13 & 2.30 & 2.64 & 3.29 & Foster Assoc. Inc., 1977 \\
\hline \multicolumn{6}{|l|}{ High Btu Synthetic Gas } \\
\hline $\mathrm{SNG}^{(d)}$ & $4.58-4.72$ & $3.19-4.99$ & $3.42-5.35$ & $3.59-5.86$ & Foster Assoc. Inc., 1977 \\
\hline Great Plains Coal & - & 3.61 & 2.79 & 2.51 & Institute, 1977 \\
\hline Interior Coal & - & 4.16 & 3.00 & 2.77 & $\begin{array}{l}\text { Stanford Research } \\
\text { Institute, } 1977\end{array}$ \\
\hline Price Regulation & 2.03 & 2.28 & 2.54 & 2.94 & Foster Assoc. Inc., 1977 \\
\hline Free Market & 2.24 & 2.42 & 2.79 & 3.47 & Foster Assoc. Inc., 1977 \\
\hline \multicolumn{6}{|l|}{ Syncrude (Coal Conversion) } \\
\hline \multirow{2}{*}{$\begin{array}{l}\text { With Government Incentives }(c) \\
\text { Without Government Incentives }(c)\end{array}$} & $3.21-3.48$ & $3.35-3.65$ & $3.61-3.89$ & $3.80-4.27$ & Foster Assoc. Inc., 1977 \\
\hline & $3.42-3.69$ & $3.56-3.86$ & $3.82-4.10$ & $4.01-4.48$ & Foster Assoc. Inc., 1977 \\
\hline \multicolumn{2}{|l|}{ Syncrude (0il Shale) } & & & & \\
\hline Foster Associates & 2.50 & 2.66 & 2.84 & 3.06 & Foster Assoc. Inc., 1977 \\
\hline SRI International & - & 2.98 & 3.09 & 3.14 & $\begin{array}{l}\text { Stanford Research } \\
\text { Institute, } 1977\end{array}$ \\
\hline \multicolumn{6}{|l|}{ Hydrogen } \\
\hline Steam Reforming & 4.21 & & & 4.58 & Salzano and Braun, 1977 \\
\hline & 5.19 & & & 5.95 & Salzano and Braun, 1977 \\
\hline Coal Gasification $(e)$ & $4.46-5.12$ & & & $4.59-5.26$ & Salzano and Braun, 1977 \\
\hline \multicolumn{6}{|l|}{ Electrolysis } \\
\hline \multirow{2}{*}{$\begin{array}{l}\text { Lurgi Water Electrolyzer }(f) \\
\operatorname{SPE}(g)\end{array}$} & 9.06 & & & 9.43 & Salzano and Braun, 1977 \\
\hline & $3.97-10.31$ & & & $4.29-10.44$ & \\
\hline \multicolumn{6}{|l|}{ Methanol } \\
\hline \multirow{2}{*}{$\begin{array}{l}\text { Natural Gas Reforming }(h) \\
\text { Coal Gasification (new) }(h)\end{array}$} & 6.82 & 7.19 & 7.53 & 7.86 & Cornell et al., 1977 \\
\hline & 6.59 & 6.59 & 6.59 & 6.59 & Cornell et al., 1977 \\
\hline \multirow{2}{*}{\multicolumn{6}{|c|}{$\begin{array}{l}\text { (a) Total well lhead cu } \\
\text { (b) Lower } 48 \text { states } \\
\text { (c) Range of Eastern, } \\
\text { (d) Range of Eastern, } \\
\text { processes. } \\
\text { (e) Range of Koppers } \\
\text { (f) Using off-peak po } \\
\text { (g) Range of off-peak } \\
\text { (h) Converted from } 19 \\
\text { Conversions Used: }\end{array}$}} \\
\hline & & & & & \\
\hline $\begin{array}{l}1035 \mathrm{Btu} / \mathrm{cf} \text { of natural gas } \\
5.56 \mathrm{mmBtu} / \mathrm{bbl} \text { of crude } 011 \\
19.52 \mathrm{~mm} \mathrm{Btu} / \mathrm{T} \text { of methanol }\end{array}$ & & & & & \\
\hline
\end{tabular}


TABLE 6. Consolidated Production Estimates for Synfuels, Crude $0 i 1$ and Natural Gas (barrel per day COE)

\begin{tabular}{|c|c|c|c|c|c|}
\hline & 1985 & 1990 & 1995 & 2000 & Reference \\
\hline Shale 0 il syncrude & 270,000 & 720,000 & $2,000,000$ & $1,500,000$ & Table 1 \\
\hline Coal Syncrude & 67,000 & 219,000 & $1,500,000$ & $1,900,000$ & Table 1 \\
\hline Synthetic Gas & 160,000 & 500,000 & --- & $1,500,000$ & Table 1 \\
\hline Crude $0 i 1$ & $19,400,000$ & $20,000,000$ & --- & $21,700,000$ & DeSteese et al., 1978a \\
\hline Natural Gas & $9,300,000$ & $8,800,000$ & --- & $7,100,000$ & DeSteese and Geffen 1978 \\
\hline
\end{tabular}


TABLE 7. Synfuel Production/Conventional Fuel Demand Comparison

$\begin{array}{lll}\frac{1985}{1990} & \underline{2000} \\ 1.4 & 3.6 & 6.9 \\ 0.3 & 1.1 & 8.8 \\ 1.7 & 5.7 & 21.1\end{array}$

Shale $0 \mathrm{il}$ Syncrude, \%

Petroleum Crude 0 il

Coal Syncrude, $\%$

Petroleum Crude 0il

Synthetic Gas, \%

Natural Gas

$\begin{array}{lll}1.7 & 5.7 & 21.1\end{array}$ 


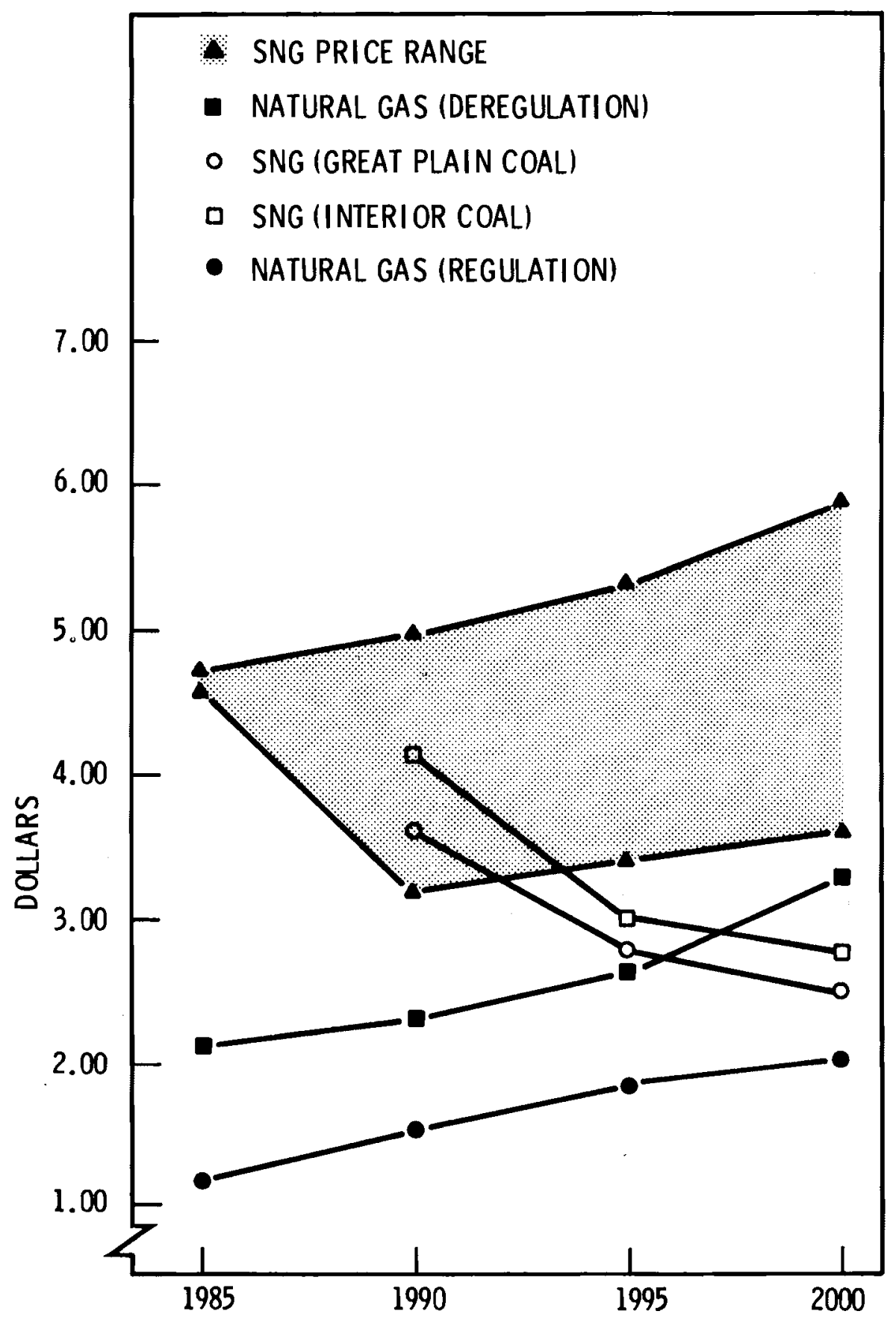

FIGURE 1. Graphical Presentation of Projected Energy Costs (Table 5) - Natural Gas and SNG 


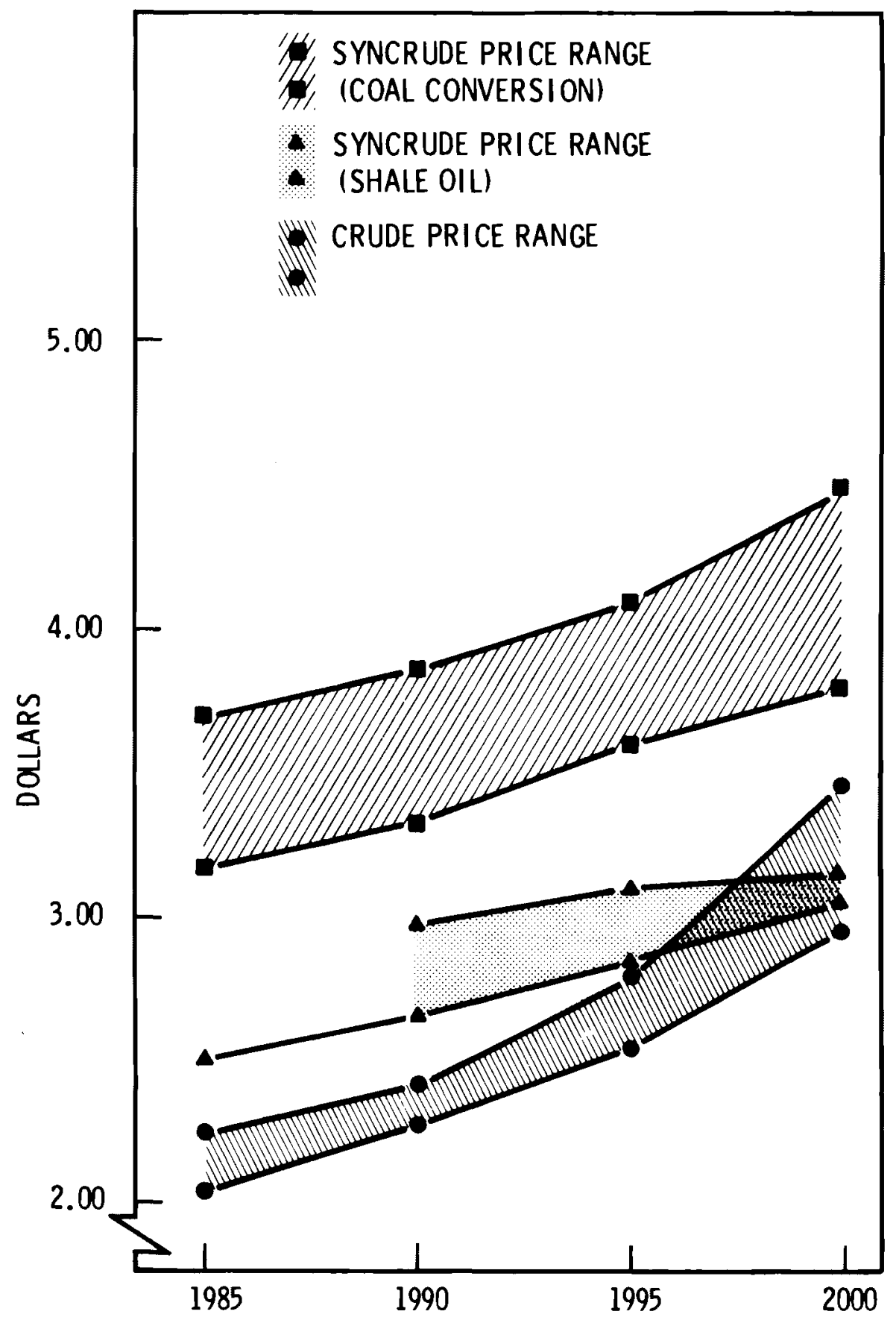

FIGURE 2. Graphical Presentation of Projected Energy Costs (Table 5) - Crude and Syncrude 


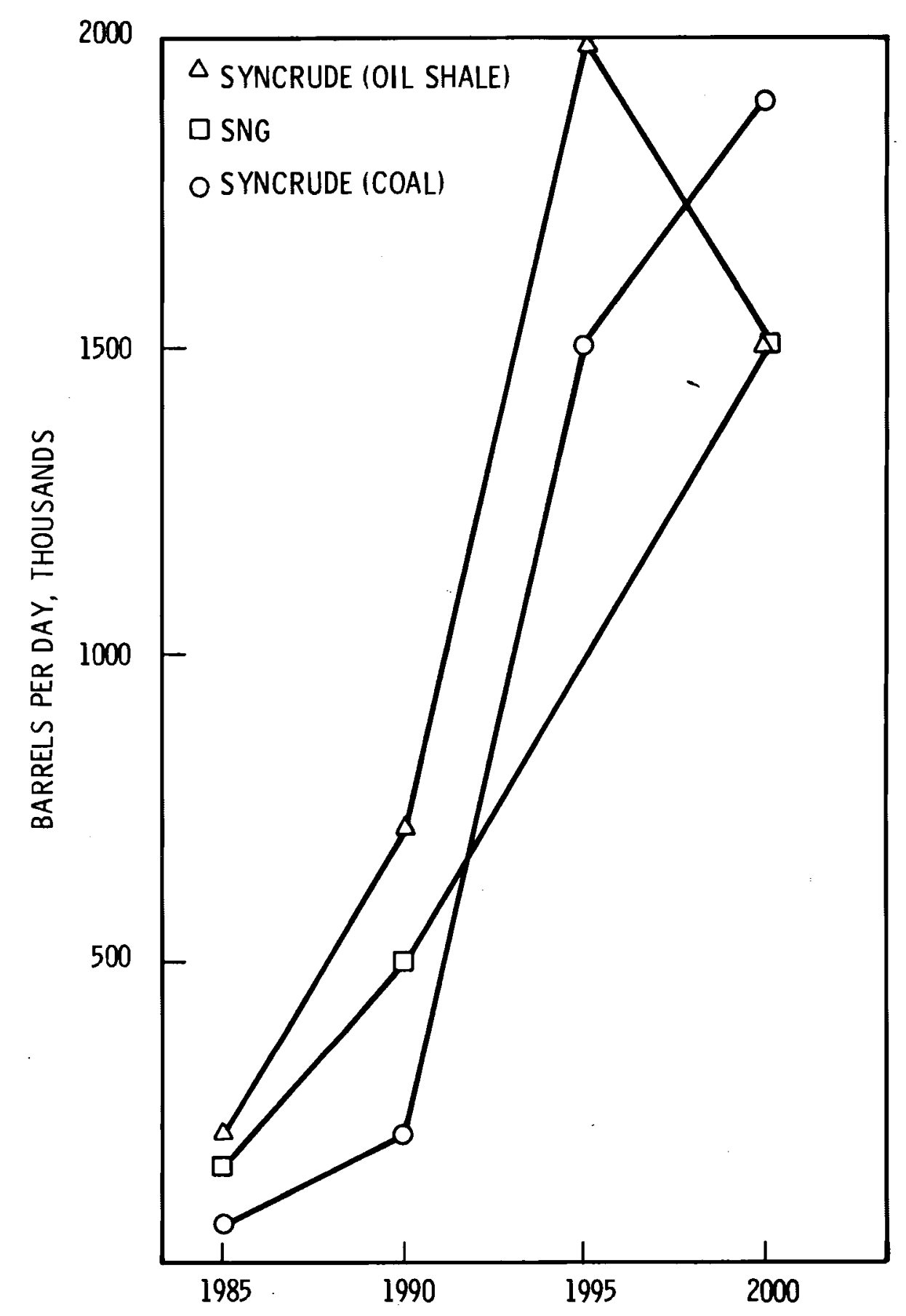

FIGURE 3. Graphical Presentation of Projected Estimates for Syncrudes and Synthetic Gas (Table 6) 
gas in the year 2000. Syncrude from oil shale and coal is expected to be relatively expensive with market prices ranging from $\$ 16$ to $25 /$ barrel crude oil equivalent. A large fraction of the price is due to high initial capital investments (Hinkle and Foley, 1976). Coal syncrude prices are projected to be higher than domestic crude through the year 2000. 0 il shale crude may become competitive with natural crude oil after 1995.

In the early 1980s steam reforming will be the most attractive methanol process because of its low investment and low operating costs. However, by the year 2000, production costs for methanol by new coal gasification processes will be substantially below those for reforming or resid partial oxidation. Predicted manufacturing cost for the year 2000 in 1975 dollars is $\$ 6.59 / \mathrm{MMBtu}$ for the new coal process compared to $\$ 7.86 / \mathrm{MMBt}$ t for reforming. Even with the reduced cost, methanol does not appear to be competitive with other liquid and gaseous fuels.

The cost of hydrogen will depend on the method of production. Initial investments and cost feedstocks will be important factors. Catalytic steam reforming should be the economically-favored method through the year 2000 with an estimated cost of $\$ 4$ to $5 / \mathrm{MMBtu}$ in 1975 dollars. Resid partial oxidation is not expected to be a significant source of hydrogen. Conventional electrolys is is the most expensive process at $\$ 9.00$ to $9.50 / \mathrm{MMBtu}$ (1975 dollars). Solid polymer electrolyte (SPE), a new procedure under development, could lower electrolysis cost to $\$ 4.00$ to $4.30 / \mathrm{MMBtu}$ using spinning reserve power (spinning reserve power is the generating capacity which is held for emergency reserve by a utility). However, this last possibility is not likely before 2000 . 


\section{TRANSPORTATION LOGISTICS}

Established transportation systems and technology will most likely be used for synfuel distribution. Syncrudes from coal and oil shale will probably utilize all modes commonly used to transport petroleum crude and its products -- pipelines, barges, rail tank cars, and tank trucks. The most probable mode of transportation for SNG will be the existing natural gas pipelines. Methanol will continue to be transported by barges and rail tank cars, and in limited cases, pipelines. Hydrogen will be transported by all of the ex isting modes.

\section{PIPELINES}

The natura 1 gas distribution included 386 storage reservoirs with 6,927 billion cubic feet capacity and 987,000 miles of field, gathering, transmission, and main pipelines in 1976 (American Gas Association, 1977b). These are potentially available for storage and transportation of SNG.

In 1976 there were 267 operating U.S. refineries with a crude capacity of 16, 170,320 barrels per day (Petroleum Publishing Co., 1977) and 227,066 miles of crude, product, and petroleum gathering pipelines (U.S. Bureau of Mines, 1977). These are potentially available for refining and transporting syncrude and associated products. Figures 4 and 5 indicate the network of gas and petroleum pipelines that could be available for synfuel transportation.

\section{BARGES}

The inland waterway system of the U.S. is comprised of approximately 25,500 miles of navigable rivers, intracoastal waterways, channels, canals, and other waterways which are available for barge transportation of synthetic crude and methanol (American Waterways Operators, Inc., 1973) as indicated in Figure 6. In 1974 more than $90 \%$ of the entire U.S. in land tank barge fleet was classified as "oil" or "D" barges (46 CFR Subchapter D) and "0i1 and hazardous materials" or "0" barges (46 CFR Subchapter 0) (Maritime Administration and U.S. Coast Guard, 1974). These barges are certified by the U.S. Coast Guard to transport crude and refined products. 


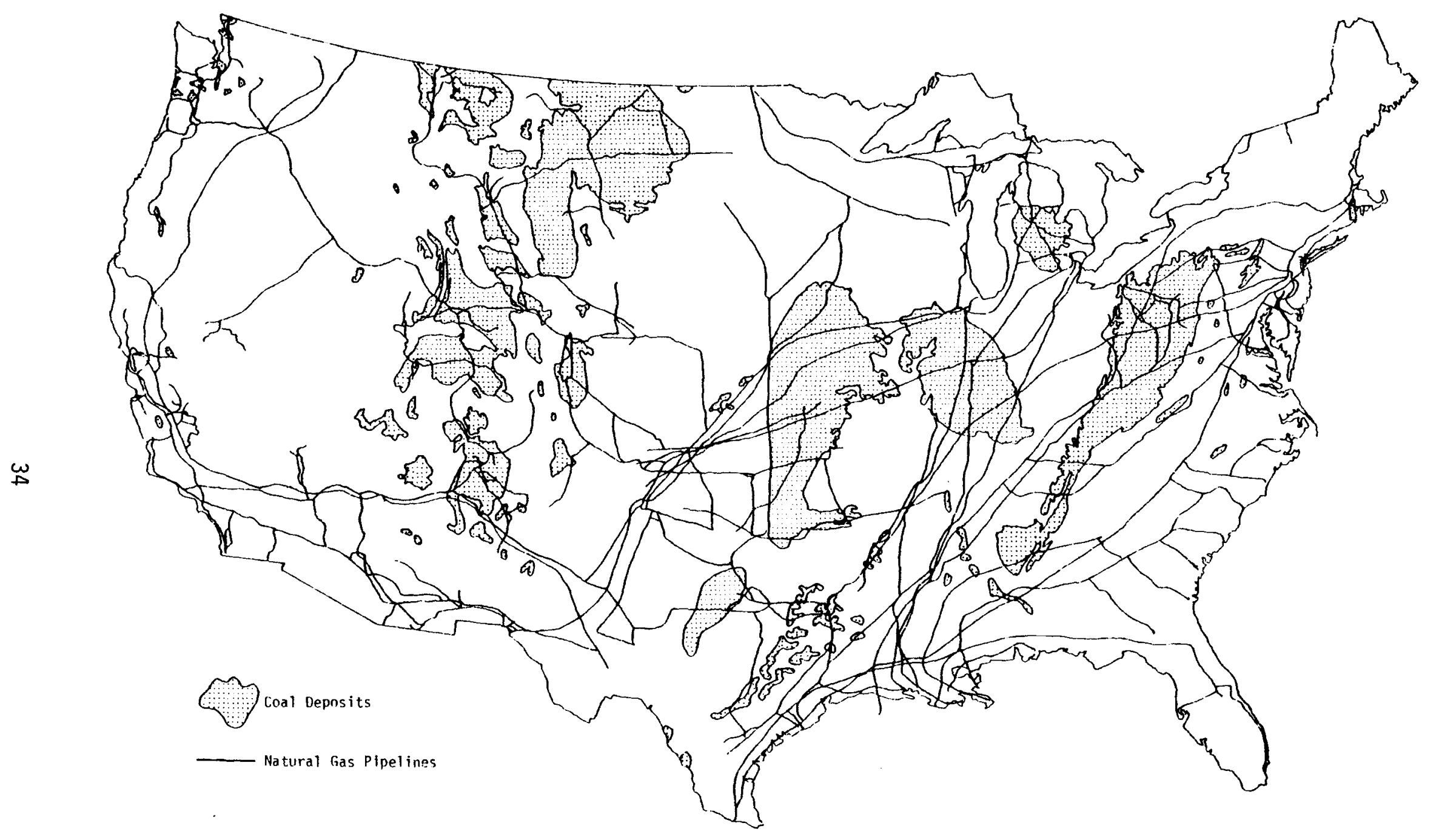

FIGURE 4. Potentially Available SNG Transportation - Pipelines 


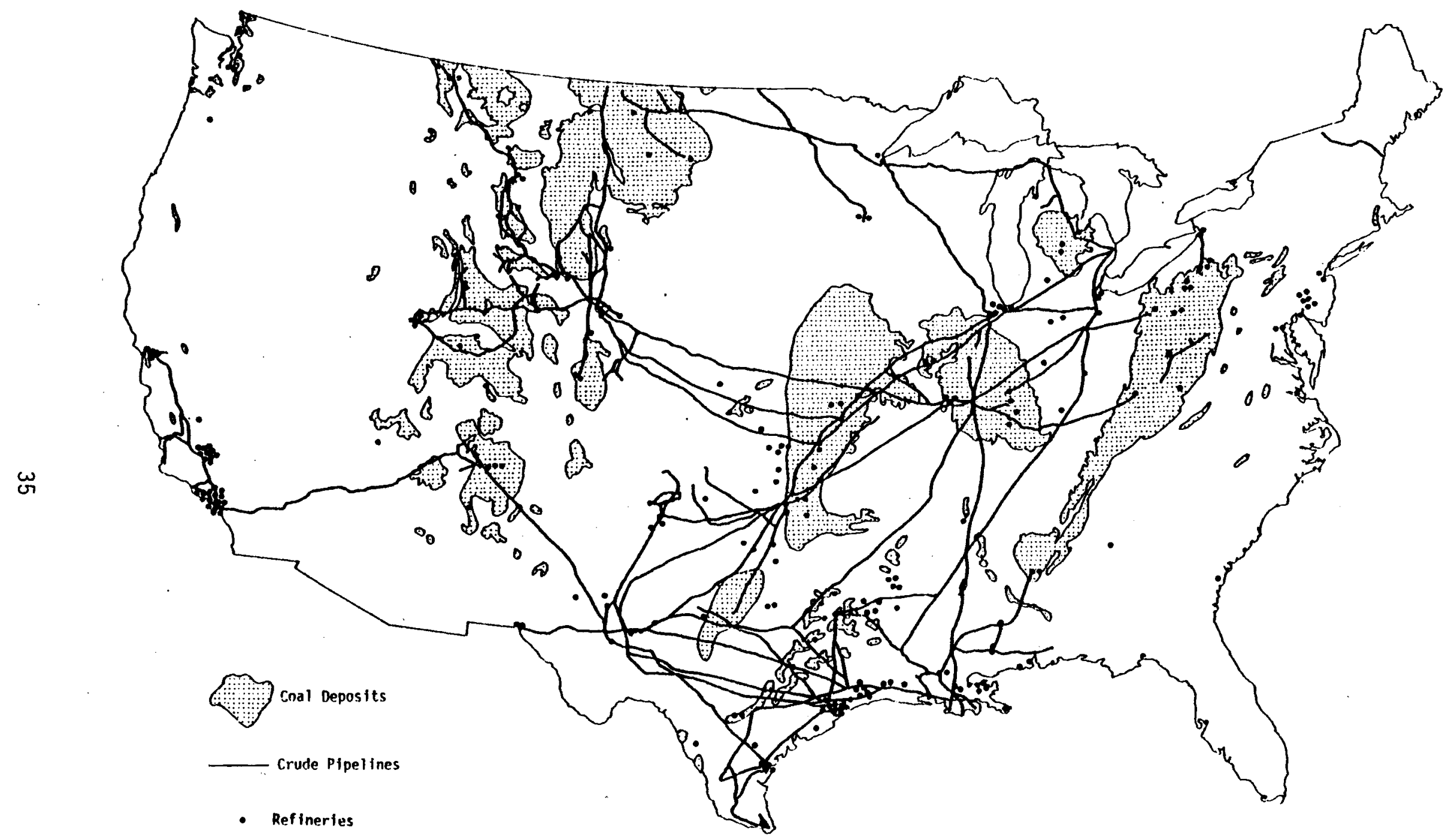

FIGURE 5. Potentially Available Syncrude Transportation - Pipelines 


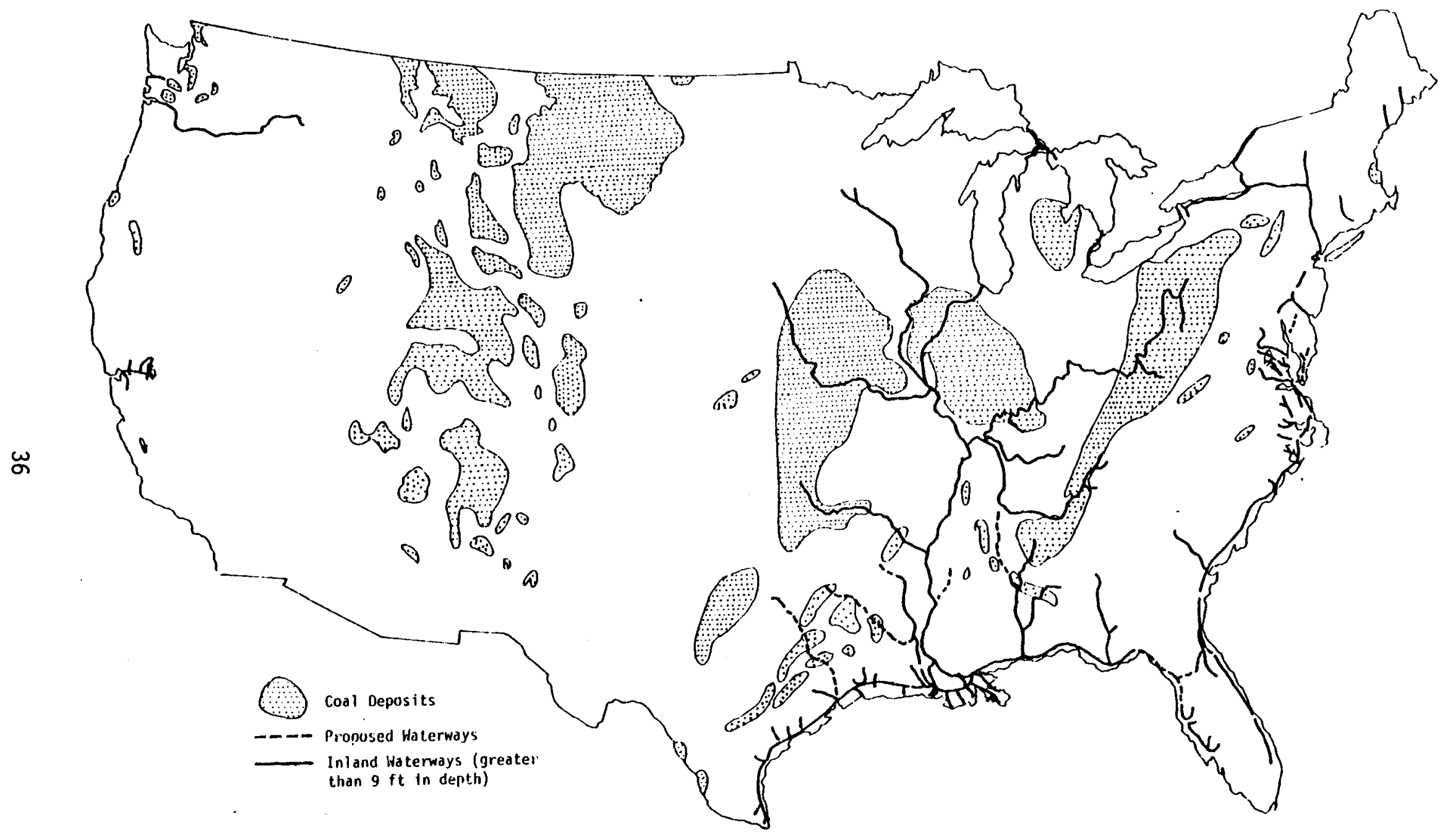

FIGURE 6. Potentially Available Syncrude and Available Methanol Transportation - InTand Waterway 
If syncrude and associated products are not significantly different in composition from natural crude and its products, these petroleum barges are potentially available. About $54 \%$ of these barges are less than 20 years old, and approximately $45 \%$ of the newer barges have double hull construction according to 1974 data.

The remaining $10 \%$ of the U.S. inland tank barge fleet is classified as "dedicated non-oil" or "0" barges (46 CFR Subchapter 0). These barges are suitable for the waterway transportation of methanol. According to 1974 data, about $71 \%$ of "dedicated non-oil barges" were less than 20 years old (Maritime Administration and U.S. Coast Guard, 1974). As of July 1, 1978, there were approximate ly 2, 140 tank barges certified to carry methano 1 (46 CFR Subchapter D). There are an additional 1,199 tank barges certified for methanol transportation (inspected under CFR Subchapters $D$ and 0 ). (a)

\section{RAILROADS}

Although railroads currently transport a smaller volume of petroleum than any other mode, the railroad is considered a potential transportation mode for syncrude. Figure 7 shows the existing rail network in the U.S. and its proximity to the coal deposits. Rail transportation of syncrude may increase as a result of limited access to pipelines for mine mouth coal liquefaction plants in the west.

According to preliminary information from ICC for 1977, total operating railroad mileage was approximately 197,151 miles for Class I railroads. There were 115,695 privately owned petroleum tank cars and 2,497 owned by railroads. The majority of petroleum tank cars owned by railroads have a capacity of between 12,000 and 19,000 gallons or 286 to 452 barrels of crude $0 i 1$.

(a) Automated Inspected Vesse 1 Data Base, USCG/DOT. 


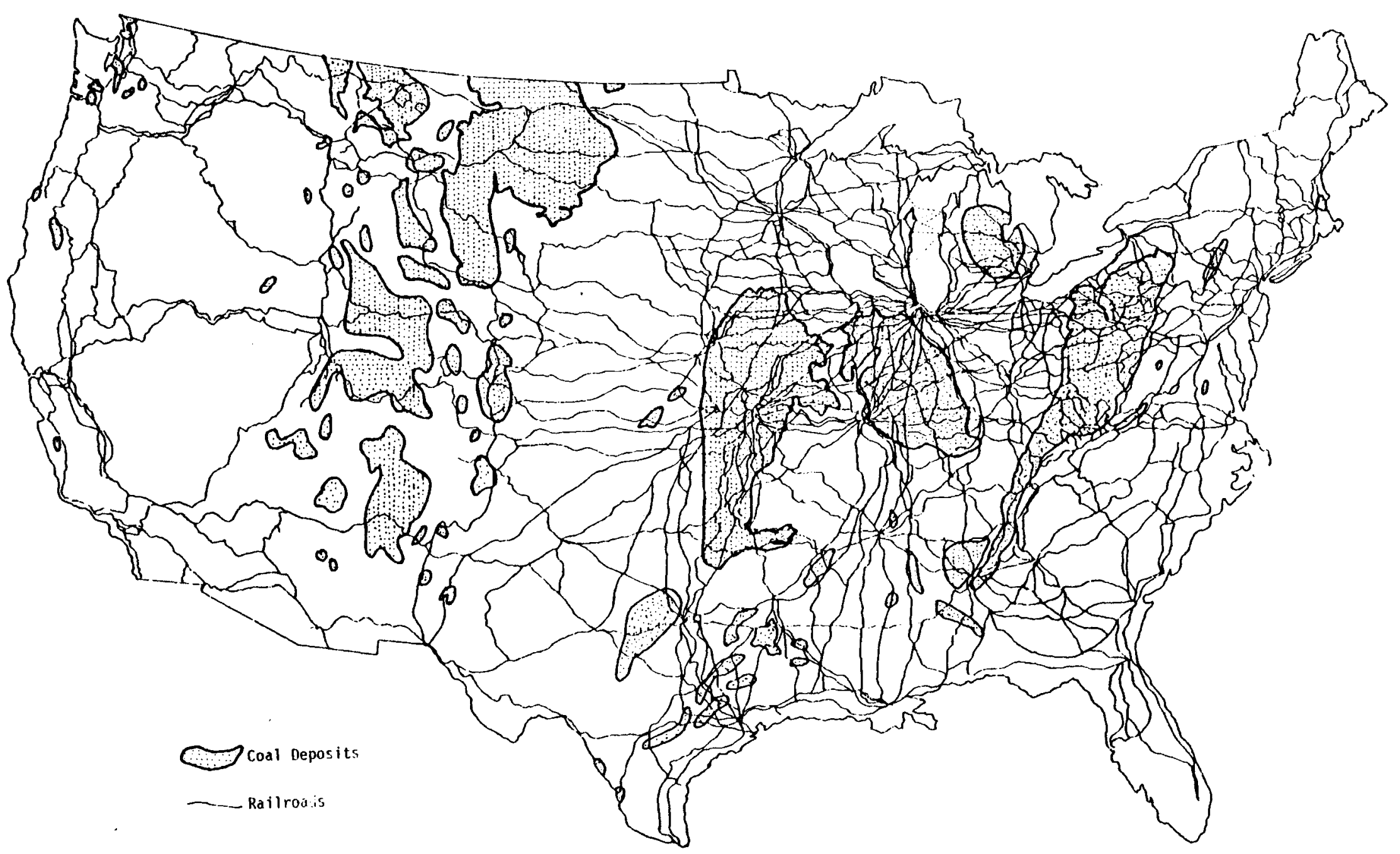

FIGURE 7. Potentially Available Syncrude and Available Methanol Transportation - Railroad 
Railroads also transport a large volume of the methanol produced for nonfue 1 purposes. One Percent Waybill Statistics for 1975 by FRA indicate capacities for methanol transported by rail ranged from 33 to 98 tons or about 116 to 344 barrels of crude oil equivalent. Waybill statistics for 1976 indicate the range of tank car capacities for methanol transported was 30 to 100 tons or 105 to 351 barrels of crude oil equivalent.

General American Transportation Corporation (GATX) has investigated transportation possibilities for syncrude (from oil shale and from coal) and methanol using Tank Tra in ${ }^{\circledR}$ tank cars. Capacities up to 250,000 barrels per day of crude oil equivalent can be transported distances of 200 to 500 miles. Currently there are two 60-car Tank Trains ${ }^{\circledR}$ in service transporting \#6 oil from Canada to the U.S. GATX report that 280 Tank Train ${ }^{\circledR}$ tank cars will be in service or under construction by the end of 1978.

\section{MOTOR CARRIER}

While long-distance movements of synfuels by truck may not be significant, delivery of small quantities for short distances will probably utilize tank trucks. Tank trucks have the unique flexibility of changing origin/ destination combination without modification to the system. Their routes are not fixed as in pipelines, tank trains, or barges. They can also transport small quantities to occasional users.

In 1972 of 158,000 tank trucks in existence, less than $20 \%$ were owned by the major oil companies (DeSteese et al., 1978). Tank trucks typically have a capacity between 5,000 to 16,000 gallons. The safety of tank truck transport is regulated by the U.S. Department of Transportation, Bureau of Motor Carrier Safety. The Bureau promulgates and administers the Motor Carrier Safety Regulations and the Hazardous Materials Regulations governing trucks operating in interstate or foreign commerce. 


\section{SYNTHETIC FUEL TRANSPORTATION SUMMARY}

Synthetic fuels are not expected to begin making significant contributions to the energy supply until the year 2000. Transportation systems for the transport and distribution of the synfuels are expected to utilize existing transportation technologies. It is improbable that synfuel plants will be sited in areas totally devoid of resources and available transportation. However, it is possible that railroad and pipeline extensions (up to 100 miles) may be necessary to transport synthetic fuels from remote plant sites to suitable junctions with the existing network. The lead times for constructing these extensions are compatible with the time typically required for plant planning and construction. Therefore, future transportation system development for the movement of synfuels appears possible without unsurmountable problems. Right-of-way acquisitions may be facilitated by natural gas pipelines and railroads having Federal rights of eminent domain. Forty-two states have granted similar rights to common carrier oil pipelines (DeSteese et al., 1978). 
POTENTIAL PROBLEM IDENTIFICATION, EVALUATION, AND RECOMMENDATIONS

Identification and evaluation of potential problems in the synthetic fuel transportation were based on system characterizations and additional information and insight obtained from contacts with experts in government and energy-related industries (Appendix B).

In many instances, sufficient information was not available to identify specific potential problems. In these cases, further study may be needed when more data become available on synthetic fuel commercialization. Syncrude and methanol transport problems that are common to petroleum and associated products have been reviewed in a companion report resulting from the Energy Material Transportation, Now through 2000 Project (DeSteese et a1., 1978). Compatibility problems in hydrogen and synthetic natural gas transportation are similarly considered in the report on national gas transportation produced by this study (DeSteese and Geffen, 1978).

\section{SAFETY OF HANDLING SYNCRUDE}

According to many industry and government officials, once syncrude has been commercialized, it will be transported in pipelines, tank barges, tank trucks, and tank cars used to transport crude oil. A thorough investigation of syncrude compatibility with current transportation modes for crude oil has not yet been made.

Although similar to crude oil, syncrude is not expected to be commingled with natural crude during transportation. Transportation standards and specifications have been established and implemented for a variety of crude oils. Therefore, current crude oil transportation technology seems to be applicable for syncrude transportation. However, syncrudes have a higher concentration of aromatic hydrocarbons than natural crude and may be more toxic and corrosive. Sufficient data are not available to determine the magnitude of the potential compatibility problem. 
The DOE's Office of Environment has conducted an analys is to evaluate effects of environmental constraints on plans to commercialize new energy technologies. This analys is is contained in a series of draft "Environmental Readiness Documents." These documents note that toxic trace metals and known carcinogenic compounds contained in liquefaction products (coal liquids) may pose serious problems to occupational health and safety. Some direct coal liquefaction processes have a moderate to high probability of causing adverse environmenta 1 impacts (McGraw-Hi11, 1978).

A thorough investigation of syncrude compatibility with existing crude oil transportation modes should be undertaken. Existing materials and specification standards should be reviewed to determine their adequacy when applied to syncrude and associated products.

\section{SHALE OIL}

$0 i 1$ shale is an abundant energy source, but is unlikely to contribute significantly to the U.S. energy supply before 1985 (Rothberg, 1978b). Unresolved issues associated with commercial shale oil production concern the development and environmental consequences of a large-scale shale oil processing plant; social and economic planning related to this industry; future leasing policies of the Department of Interior; tax policies related to oil shale development; and the establishment of a comprehensive national oil shale policy. No single issue can be identified as the major factor limiting commercialization of the shale oil industry. Instead, the combination of factors and their synergistic effects is likely to keep the contribution of shale oil to the U.S. energy supply at a low level for at least the next 10 years.

Since the major oil shale development is in the semi-arid regions of Colorado, Utah, and Wyoming, water availability is also a serious issue. The major water demands for the oil shale development will be for spent shale disposal (in the case of above ground retorting), raw shale oil upgrading to syncrude, power generation, and the associated urban usage. Water requirement for an ultimate shale oil syncrude production of one million barrels per day 
is estimated at an upper range between 62,000 and 75,000 million gallons per year (Committee on Future Energy Prospects, 1977). This demand might be reduced significantly to 39,000 to 46,000 million gallons per year if crude shale oil upgrading and power generation were performed offsite (Comittee on Future Energy Prospects, 1977).

The U.S. Department of the Interior conducted an environmental impact study on the oil shale regions of Colorado, Utah, and Wyoming in 1973. This study shows that approximately 111,000 million gallons per year of water are potentially available for the oil shale development. This supply of water is not assured during the months of reduced river flow without impinging on senior water rights. Therefore, the maximum possible growth for the oil shale development would be about 2.6 million barrels per day, according to these data, if raw shale oil were upgraded out of the region.

Further study is necessary to determine the quantity of water that can be used for the shale oil development. Water supply-demand balances should be made to determine the possible size of this development. Water availability will influence strongly the siting of the upgrading facility and therefore determine the transportation system required.

\section{Transportation}

The method for shale oil transportation will depend on water availability at the development site. If there is enough water to upgrade the syncrude, the upgraded syncrude may be compatible with the existing modes for transporting crude oil in the vicinity of the development. The most likely distribution will be through the existing pipeline network for crude oil (see Figure 4). Additional pipelines will need to be incorporated into the existing system between the syncrude production sites and the existing network if pipeline distribution is to be used.

If enough water is not available, an alternate transportation system must be devised to handle the raw syncrude. Crude shale oil must be transported out of the region for upgrading and solvent additions may be necessary to reduce viscosity. Transportation system development for crude shale oil may then differ from that of a petroleum crude, depending on the solvent added. 


\section{Regulations}

Although industrial representatives consider petroleum pipelines as the most likely mode for transportation of syncrude, documentation to validate this opinion has not been identified. If petroleum pipelines are used for syncrude transport, it appears probable that DOE will have principal economic regulatory authority and DOT will have jurisdiction similar to that exercised for petroleum pipelines. Economic regulation of interstate petroleum pipelines, the establishment of rates, charges, and valuations is provided by the Federal Energy Regulatory Commission (FERC). FERC also has author ity to establish and enforce oil pipeline common carrier duties. Safety, design, construction, and operation of oil pipelines are regulated principally by the Office of Pipeline Safety Regulation (OPSR).

Some economic regulations of intrastate pipelines is provided by State laws. More than half the states have laws for economic regulation and states have right-of-way laws. Conflicts can arise when pipelines that operate inter- and intra-state must comply with both Federal and State regulations (DeSteese et al., 1978).

No new regulations, economic and/or safety, for pipeline transport of synthetic crude have been formulated to date. Regulations currently class ify syncrude as a flarmable liquid according to petroleum standards and specifications, 49 CFR 172, 173 (see Appendix C).

Economic regulation over water carrier operations of bulk products, i.e., establishment of carrier rates, is primarily a responsibility of the carrier management. 0il allocation and pricing regulation are authorities of DOE. DOT has principal safety jurisdiction over water carriers (tank barges, tankers). The Coast Guard is the safety enforcement agency and regulates construction, manning, operation, maintenance, inspection, and certification of tank barges, 33 CFR 80-86 (see Appendix C). The Corps of Engineers, Department of the Army, is responsible for maintenance, construction, and developmental activities of Federal water resources which directly affect all inland waterway transportation. 
Economic regulation of interstate railroads is under ICC jurisdiction. However, the establishment of carrier rates is the responsibility of carrier management. Rate proposals must be filed with the ICC and, in most cases, they become effective. If the proposals are protested, ICC can intervene, suspend, investigate, and either uphold or cancel the rate proposal. Railroads have the right of eminent doma in for interstate and intrastate railroad construction. Construction plans for a railroad are submitted to the ICC, which has the right to review and approve such plans. Approval of state public utility commissions is also required for new railroad construction. Railroads can purchase land, gain easements or condem land (according to various state statutes) for new, approved railroad construction.

The Federal Railroad Administration (FRA) of DOT has primary jurisdiction over railroad safety. The FRA is responsible for the implementation of track and freight car safety standards, railroad safety appliance standards, locomotive inspection, railroad operating rules, and other installation and maintenance regulations contained in 49 CFR 200-299 (see Appendix C). Enforcement of regulations pertaining to railway transportation of hazardous materials is the responsibility of the Department of Transportation. The DOT exercises th is enforcement responsibility through the FRA. Any incidents involving release of hazardous materials during the course of transportation, loading, unloading, or storage are required to be reported to the Office of Hazardous Materials Operations (OHMO), Materials Transportation Bureau (MTB), DOT in accordance with 49 CFR Subchapters B and C (see Appendix C).

There are numerous other agencies involved in the transportation of energy materials. Only the major agencies have been identified in this report.

\section{COAL CONVERSION SYNFUELS}

Coal conversion synfuels may be produced at remote, we11-regulated plants to avoid contributing to the primary pollution problems that exist in urban centers. In the West, coal can be used to produce fluid fuels (liquefaction) which could be transported to refineries or demand centers far from the coal mines. The National Petroleum Council (NPC) assumes that any coal conversion synfuels produced prior to 1985 would use the large surface minable reserves 
in the West as coal feedstocks (Fuel Task Group on Coal Availability, 1973). It appears that the lower cost of those reserves would more than offset the greater cost of transporting synthetic fuels to demand centers.

The siting of coal conversion plants could place other demands on transportation systems. If the conversion plants are located at the coal mine mouth, waste disposal (i.e., ash) would place few, if any, demands on transportation systems. If the plants are located elsewhere, new transportation systems may be required for waste disposal.

Transportation - Coal Gas

Synthetic natural gas (SNG) is the only one of the three coal gases (high-, medium-, and low-Btu) that can be commingled with natural gas, and is capable of being transported in the existing natural gas pipeline network. In addition, SNG can use natural gas storage facilities that are under-utilized as a result of the declining supply of natural gas. Process plants which are used for removal of the 5 to 10\% propane and/or butane in raw natural gas can also be used for SNG processing.

Medium-Btu gas is being considered for direct sales to industry for use in operations and/or equipment that will not be adversely affected by boiler derating and do not necessarily require highest quality gas, but do require an uninterrupted gas supply. If there is sufficient industrial demand, a special pipeline distribution system would be required to transport the medium-Btu gas because it cannot be commingled with natural gas (Richardson, 1975). According to a Union Carbide analys is of the investment required to comercialize various feedstocks and energy alternatives, medium-Btu synthes is gas from coal would not be competitive with synthesis gas from oil until 1985.

Low-Btu gas (fuel gas) also is not amenable to commingling with natural gas or suitable for pipeline transport (Rothberg, 1978a). This resource is familiar to some in the U.S. as town gas. Some town gas plants still exist in New Jersey. The low heating value makes transportation by pipeline over any distance uneconomical. 


\section{Transportation - Coal Syncrude}

The most likely distribution for coal-derived syncrudes is through the existing crude oil pipeline network (Hinkle and Foley, 1976) as illustrated in Figure 5. Depending on the location of liquefaction plants, some new pipeline additions and expansions may be necessary. Unless synthetic crudes and products contain corrosive chemicals not previously considered by the American National Standards Institute (ANSI) for pipeline transport, most of the existing petroleum pipeline network could be utilized for synthetic crude transport when the demand rises.

The potentially available pipeline transportation network for syncrude is not as extensive as the pipeline network available for SNG transport. As Figure 5 indicates, the crude pipeline network is predominantly located in the central two-thirds of the U.S. East and West Coast states are basically served by waterway transportation and receive crude by barge and tanker shipments. Most of the refineries are located in the states served by pipelines.

Coal deposits are also located in the central two-thirds of the U.S. Proximity of the pipelines and the refineries, and location of coal deposits are some of the reasons for siting liquefaction plants in the coal resource states. Other studies have indicated use of coal slurry pipelines to transport coal to demand centers/industrial centers where syncrude would be produced, refined, and distributed (Fuel Task Group on Coal Availability, 1973; Braunste in et al., 1977). It is probable that liquefaction plants will be sited in areas where transportation systems are already in place.

Unrefined syncrude, like natural crude oil, will have almost no market other than as a refinery feedstock. Therefore, the bulk of syncrude will be tranported to refineries. It is anticipated that existing pipelines and refineries will be used whenever possible. The absence of crude oil pipelines in many coastal states has little consequences since these areas are generally served by water transport. Refined products (e.g., distillate fuel oil, gasoline, kerosene) already have markets and transportation networks established. 
Therefore, it appears that adequate transportation exists for commercialization of syncrude industry, if syncrude is compatible with transportation technologies for crude oil.

Tank barges used for conventional petroleum transportation are believed to be also suitable for syncrude transportation. Special requirements have been implemented for barges that transport petrochemicals (i.e., 46 CFR Subchapters $D$ and 0 , Appendix $C$ ), but there are no new barge requirements for the transport of synthetic crude and products on the inland waterways. Utilization of the existing waterway transport for petroleum is currently envisioned. The likelihood of new requirements will depend on assessments of the compatibility of syncrude with petroleum transport systems.

In the early years of anticipated syncrude production (1995 to 2000) it is estimated that less than $10 \%$ of the petroleum supply will be produced by the coal syncrude industry. Unless an unforeseen event causes comercialization to occur more rapidly than anticipated, it appears unlikely that tankers will be required to transport syncrude between U.S. ports before the next century.

Although railroads currently transport only a small volume of crude $0 i 1$, with the advent of a commercial synthetic crude industry, rail may become increasingly significant.

Transportation - Methanol from Coal

Distribution systems for transportation and storage of methanol (petroleum feedstock) which is already a commercial petrochemical commodity have been fully developed and demonstrated (Johnson, 1972). Methanol plants using coal feedstocks should be located in geographical areas with low cost high-Btu coal available and serviced by low cost transportation systems. East Coast and possibly mid-continent areas would correspond with the se requirements.

Methanol is shipped in tank cars and tank barges and some is moved by pipeline. Although there are a number of pipelines that transport methanol to chemical plants, there is no pipeline network for the interstate transportation of methanol (Arthur D. Little, Inc., 1974). Methanol will continue to be 
transported to major distribution centers by existing modes until the industry becomes sufficiently large with established markets to warrant pipeline construction (Hinkle and Foley, 1976). According to both government and industry officials, pipeline construction for methanol transportation is unlikely to occur in th is century.

Specific statistics on barge transportation of methanol are unavailable. Th is is because methanol (methyl alcohol) is classified as an alcohol in the U.S. Army Corps of Engineers domestic waterborne commerce statistics. Alcohol is code number 2813 of group number 28 - Chemical and Allied Products, and includes glycerin, glycol ethers, varieties of glycols, synthetic alcohols, fatty alcohols, and miscellaneous organic, industrial, and other organic chemicals including intermediates as well as methanol.

Statistics available for railway transport of methanol are from the Federal Railroad Administration (FRA) and for incident data from the OHMO. Carload $1 \%$ waybill statistics (FRA) indicate approximately 3,800,000 ton miles of methanol traffic for 1975 and approximate ly 5,320,000 ton miles for 1976 . Extrapolated total ton mileage for methanol during 1975 and 1976 is 380 million and 532 million, respectively.

There were 9 railroad incidents with 1 injury in 1975 and 19 railroad incidents with no injuries in 1976 associated with the transportation of methano 1. (a) The majority of railway incidents involving methanol were loose or defective fittings, valves or closures. Eighty-nine percent of reported incidents in 1975 and 58\% of those reported in 1976 were attributed to fitting, valve, or closure failures. From information provided by the FRA and OHMO it was calculated ${ }^{(b)}$ that in 1975 one incident involving methano 1 occurred every 42 million ton miles. For 1976, one incident with methanol occurred in 28 million ton miles of rail transportation.

A study completed for the Maritime Administration in 1974 reported tota 1 shipping costs per ton of methanol transported were about 5.3 times greater

(a) Source: Based on incident information from OHMO, DOT.

(b) $\frac{(1 \% \text { Waybi } 11 \text { Statistics })(100)}{\text { No. of Incidents }}=\frac{\text { Ton Miles }}{\text { Incident }}$ 
for rail than for barge (Arthur D. Little, Inc., 1974). The special handling costs included in the loading and discharge costs for methanol were responsible for the higher rail shipment costs. Barge transportation was less expensive because decreased manpower and time were required for these operations. However, the unit tank tra in concept may impact methanol transportation by decreasing rail transport costs as we 11 as loading and discharging times and manpower requirements. GATX is exploring the possibility of transporting methanol in non-coiled, non-insulated Tank Trains .

\section{Regulations - Coal Conversion Synfuels}

It is anticipated that economic and safety regulations for pipeline transport of SNG will be basically the same as those for the natural gas pipelines. The DOE Organization Act of 1977 is the empowering legis lation which granted the Federal Energy Regulatory Commission (FERC) major economic and regulatory control over the interstate natural gas industry. FERC establishes and enforces rates and charges for natural gas transportation and sale, estab1 ishes producer and gatherer prices, and issues certificates for natural gas transportation and sales. FERC has eminent domain authority for interstate pipeline construction and environmental authority over SNG facility siting.

The Office of Pipeline Safety Regulation (OPSR) of DOT is responsible for safety regulations for interstate natural gas pipelines and is the source of annual statistical reports on pipeline accidents. Technical standards for natural gas pipe and valve materials, welding, construction, repair, and inspection are included in the OPSO regulation, 49 CFR 190-199 (Appendix C). Since SNG will be commingled with existing supplies of natural gas and pipelines will be the principal mode for transportation for SNG, it is apparent that FERC and OPSO will be the major cognizant regulatory authorities.

Economic regulation over intrastate natural gas pipelines, transmission and distribution utilities is provided by the various state public utility commissions. States usually have eminent domain regulation and many, through state agencies, participate with OPSO in safety regulation of interstate pipelines. 
Regulations applicable to coal conversion syncrudes should be the same as shale oil syncrudes. Syncrudes are classified as a flamable liquid according to petroleum standards and specifications (see Appendix $C$ ).

Methanol transportation regulatory authorities for rail and in land waterway should also be the same as those for syncrude. Both syncrude and methanol are classified as hazardous materials but applicable regulations for shipping and packaging may vary for each. See Appendix $D$ for further information on hazardous materials shipping regulations.

HYDROGEN

In selecting a hydrogen transportation system, the ideal approach would be to devise several delivery methods from producers to users and then choose the methods with the best technological and economical characteristics for specific applications. This may not be possible for the hydrogen market, at least not in the near future. The immediate issue is not the devising of opt imal hydrogen delivery and storage system but the expansion of the distributing capacity of an already active industry. Hydrogen users have only limited options available. Primarily, these are to acquire an in-house hydrogen production capability (captive hydrogen) or to accept hydrogen in the more expensive liquid form. For this reason, the merchant hydrogen market will probably remain relatively small for as long as natural gas and petroleumfraction feedstocks remain economically available.

As mentioned previously, the bulk of present hydrogen consumption is in the form of an intermediary in the chemicals industry. The growth patterns of these processes indicate that this use will continue to dominate the hydrogen market for the next decade or two. In developing a comprehensive hydrogen delivery scenario, particular attention should be paid to both the form in which hydrogen is supplied and that in which the user desires it. Future hydrogen transportation scenarios are sumarized in Figure 8 . The possible applications and assessments of each transportation method will be discussed in the following subsections. 


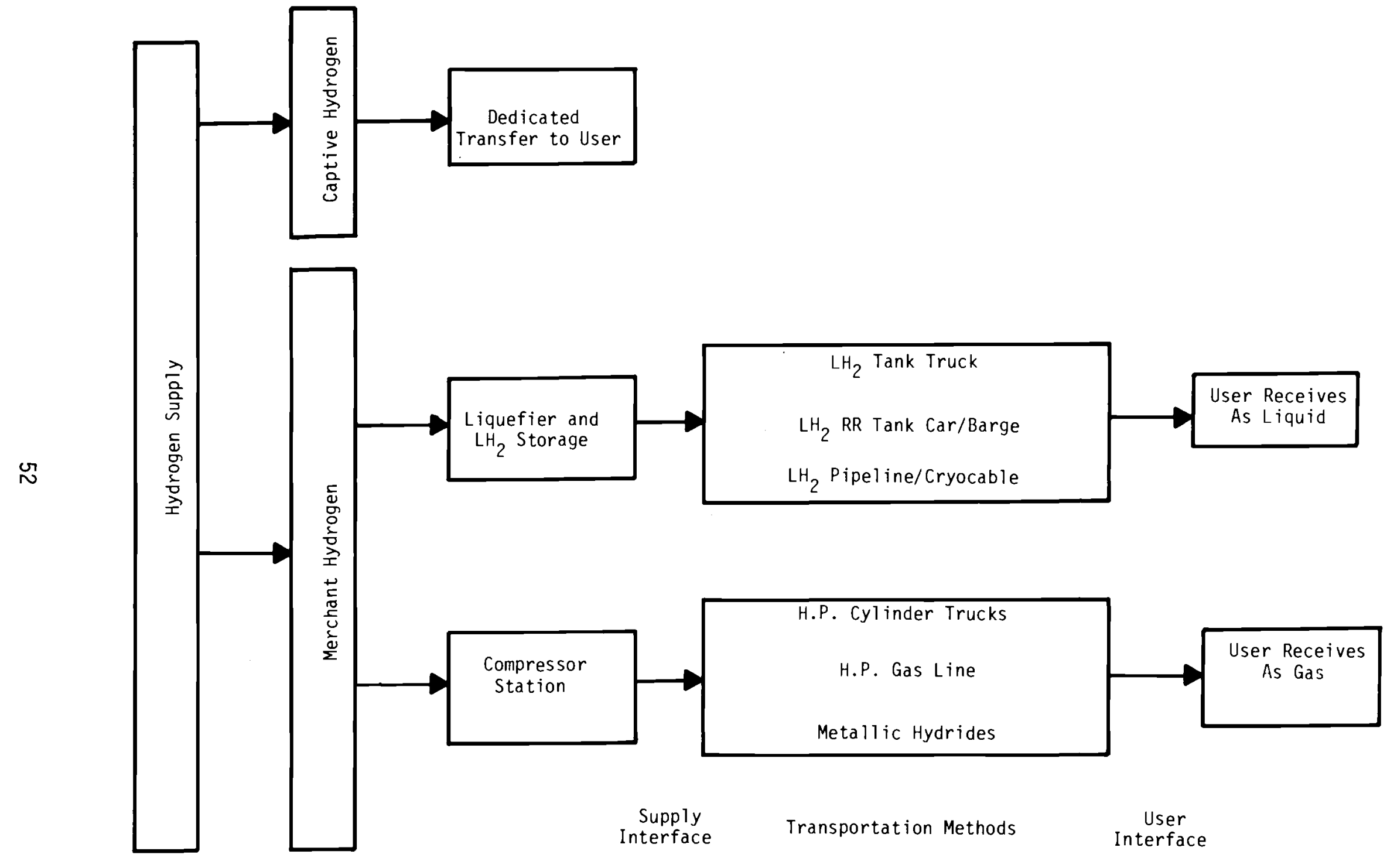

FIGURE 8. Hydrogen Transportation Scenarios 
Gaseous Hydrogen

All current and proposed methods for the production of hydrogen result in gaseous hydrogen rather than a liquid or a hydride. Since hydrogen will be produced and ultimately used as a gas, it might seem advantageous to store and transmit hydrogen in the gaseous form. Results of studies indicate that the storage of gaseous hydrogen in pressure vessels is not competitive with other alternatives over the full range of storage capacity (Synthetic Fuel Panel, 1972). This is due to two factors: the low density of gaseous hydrogen even at high pressures, and the high cost of pressure vessels. These factors cause compressed gas storage of hydrogen to be bulky and capital cost per unit of stored energy to be high for gaseous hydrogen. There are some specific, typically small-scale situations for which compressed gas storage of hydrogen is warranted and is presently used. For example, hydrogen gas tube trailers are currently used for short range distribution (100 to $150 \mathrm{miles}$ ), and the quantities handled are small (usually 150,000 $\mathrm{ft}^{3}$ ). However, for the reasons sited above, large-scale hydrogen use does not appear likely to involve storage in pressure vessels.

Bulk hydrogen fuel could be supplied by gas pipeline. Thus, hydrogen would be distributed in the same form as it is produced and eventually used. The pipeline could also serve as an inventory device (line packing). Such an approach is used in the 130 mile-long Ruhr-Valley hydrogen pipeline in west Germany (Weil, 1972). A 2-ft diameter, 300-mile long pipeline holding hydrogen gas at 1000 psia would store $1.7 \times 10^{6}$ lb or $9 \times 10^{10}$ Btu. However, line packing will probably be unimportant as a storage technique for hydrogen. Line-pack storage can only meet daily needs; seasonal peak-shaving requirements must be satisfied by large-scale storage.

Large quantities of gaseous hydrogen may be stored in mined caverns, aquifers, depleted oil and gas wells, or in bladder devices. An aquifer storage system at Baynes, France, with a capacity of $7 \times 10^{6} \mathrm{ft}^{3}$ at 570 psia, has been in operation for over 10 years; in itially with manufactured gas and currently with natural gas. Economically, this approach seems promising. The Synthetic Fuel Panel (1972) cites' a capital cost of $\$ 3$ to $\$ 6 / 10^{6}$ Btu for large underground storage in aquifers, and $\$ 350 / 10^{6}$ Btu for 
storage in $866,000 \mathrm{ft}^{3}$ mined caverns at 900 psig (1972 dollars). However, more work is needed to establish the feasibility of these various approaches with hydrogen and their ultimate potential. If gaseous hydrogen is to be stored and transmitted on a large scale, the only practical method seems to be storage in large natural underground reservoirs and transmission by pipeline.

The development of a hydrogen pipeline system can be accomplished in several ways but there are many indeterminate factors which would affect the development. Presumably, some of the existing natural gas pipelines will be incorporated into the hydrogen network. The location of the hydrogen plant with respect to the existing natural gas systems is important. Existing natural gas pipelines could be used to transmit an equal amount of energy in the form of hydrogen gas, but such a system would require approximately four times the present compressor capacity and over five times the compressor horsepower (Gregory, 1972). This would not be the optimal design for the compressor; however, if the existing natural gas pipelines could be used, the overall cost of such a system would be favorable when compared to the cost of a new optimized system.

The existing natural gas transmission lines originate in the Southwest and deliver gas to the Midwest, and the East and West Coasts, but it is unlikely that hydrogen would be generated in the Southwest. It may be more economical to generate hydrogen closer to the large markets in the coastal areas. If this were the case, new transmission mains from the hydrogen plants could be added to the existing distribution systems along the coast. Since the coasta 1 areas are at the end of the present natural gas pipelines, it would be possible to convert a large coastal area to hydrogen while inland areas are allowed to continue using natural gas. This would provide a gradual conversion of the existing natural gas distribution systems to hydrogen.

The possibility of converting existing natural gas distribution pipelines to hydrogen also exists. Since the distribution system is generally a lowpressure system, it is possible that existing natural gas distribution piping would be adequate to handle the required volume of hydrogen gas without danger of hydrogen environment embrittlement (hydrogen embrittlement is discussed in a subsequent subsection). 
The manner in which a hydrogen pipeline system may develop is not totally predictable. A hydrogen system may initially be constructed parallel to the existing natural gas system. A more likely scenario, however, is a hydrogen system for only the newly developed areas. Also feasible is the use of hydrogen as an industrial and electric generation fuel in a new pipeline system.

When considering the use of existing natural gas pipelines for transmission of hydrogen gas, there are two major factors to be resolved (Gregory, 1972; Reynolds and Slager, 1972). One of these factors is the change of compressor capacity needed to pump hydrogen. The other factor is the metallurgical problem associated with switching from natural gas to hydrogen.

\section{Compressors}

Hydrogen transmission may have an adverse effect on the existing pumping station machinery, both in performance (as ability to produce sufficient pressure increases) and flow rate in the efficient manner, as well as operating life-time. At present, in the natural gas industry, two major types of compressors are used to boost the pressure in the transmission lines. These are reciprocating compressors ( $p$ iston type) and centrifugal compressors. The centrifugal compressor has largely replaced the reciprocating compressor in pipeline service because of lower initial cost and maintenance expense. Both designs will suffer to one degree or another from hydrogen embrittlement depending on the materials chosen for the design. Reciprocating compressors may have a serious sealing problem due to the rapid diffusion of relatively small $\mathrm{H}_{2}$ molecules and the effect of $\mathrm{H}_{2}$ on sealing materials in nonlubricated designs. Centrifugal compressors will not produce the required pressure ratio without extensive multistaging; since pressure rise is the product of density and head rise, a lower density gas requires a higher head machine. Both types of compressors would have to be built in larger capacities to deliver hydrogen at an equivalent energy potential as natural gas. This is because at 750 psi, hydrogen has on $1 y 26 \%$ of the energy capacity of methane (Wurm and Pastris, 1973). 
A possible solution to the design difficulty of a compressor is to use the regenerative compressor. Regenerative compressors are capable of making the head in a single stage that would normally require seven to eight centrifugal stages.

\section{Hydrogen Embrittlement}

Hydrogen embrittlement may occur if existing natural gas pipelines are used for hydrogen transport. There has been no known research performed on pipeline steels regarding susceptibility of metals to hydrogen embrittlement. However, there has been work performed on stee ls that are in the same low carbon steel alloy class. These investigations indicate this class of stee 1 undergoes severe hydrogen embrittlement when exposed to high purity hydrogen at high pressure.

The effects of hydrogen on metals and alloys have been investigated for over 50 years, but extensive work has been performed only in the last 2 or 3 decades. There are three broad classifications of hydrogen embrittlement: 1) hydrogen chemical reaction embrittlement; 2) internal reversible hydrogen embrittlement; and 3) hydrogen environment embrittlement.

The first class of embrittlement is caused by chemical reactions of hydrogen with the metal or alloy constituents. Th is form of hydrogen embrittlement manifests itse if in the formation of compounds such as metal hydrides, water, and methane. For example, the formation of methane gas internally in the steel lends to fissures, blistering, and cracking.

The second class of embrittlement has been well researched. Even though the phenomenon and the factors that influence it are well known, the exact mechanism is still not well defined. The phenomenon occurs by the absorption of hydrogen in the form of an atom or ion into the internal structure of the metal. After an interval of time, which can be as long as years, catastrophic failures of the metal may result.

The last type of hydrogen embrittlement appeared unexpectedly in the aerospace industry about the mid-1960s. Several storage tank failures were not explainable by either of the two prior classifications. This phenomenon 
is characterized by the formation and growth of surface cracks in a metal or alloy while being plastically deformed in a high purity hydrogen gas environment.

The potential exists for hydrogen embrittlement problems to occur in components required by any hydrogen transportation and storage system. To be economically competitive, these components (pipelines, storage vessels, compressors, etc.) are likely to be operated under more adverse conditions than currently in practice. The attempts to use cheaper materials or existing materials under more extreme conditions could lead to serious failures. The use of existing pipeline is further complicated by the wide variety of material used and the diversity of weld qualitities. Continued research on fabrication, testing, and designs is necessary to overcome the problem of hydrogen embritt lement.

\section{Liquid Hydrogen}

Hydrogen as a liquid fuel has the advantages of relatively high density, ability to absorb large quantities of heat as its temperature is raised, and low-pressure (low-weight) containers. However, liquid hydrogen also has disadvantages, such as theoretical and practical thermodynamic inefficiencies, transfer losses, chilldown losses, steady-state boil-off losses, and the potential for a large fire from a small liquid-hydrogen spill.

Transport and storage of hydrogen has undergone considerable improvements in recent years mainly due to the large quantities of liquid hydrogen used as fuel in the space program and the liquid hydrogen stored at the Nuclear Rocket Development Station in Nevada. The quantities needed in these two programs were so large that the development of improved pumps, pipes, tankers, and storage containers became necessary.

Once cryogen ic hydrogen has been liquefied and then purified to the required quality, a transfer and storage system is necessary. The primary objectives of any cryogenic transfer and storage system are to minimize cryogenic fluid losses and maintain the desired transfer rates with a system that is economical, reliable, and safe. Losses during handling and transfer are 
significant and it is not difficult for large quantities of liquid to be lost when improper handling techniques are employed. Examples of some liquid hydrogen handling and transfer experience are shown in Table 8.

TABLE 8. Liquid Hydrogen Handling and Transfer Experience (Cole et al., 1975)

\begin{tabular}{|c|c|c|}
\hline Operation & Scale & Loss \\
\hline $\begin{array}{l}\text { Liquefaction Plant } \\
\text { Air Products, Inc. }\end{array}$ & $\begin{array}{l}3 / 4 \text { ton/day } \\
\text { Plainesville, Ohio }\end{array}$ & $15 \%$ \\
\hline $\begin{array}{l}\text { Liquefaction Plant } \\
\text { Air Products, Inc. }\end{array}$ & $\begin{array}{l}30 \text { tons/day } \\
\text { West } \mathrm{Pa} / \mathrm{m} \text { Beach, Florida }\end{array}$ & $10 \%$ \\
\hline Saturn V Launch & 46,000 gallons & $25.5 \%$ \\
\hline Los Alamos Batch Transfer & 1,450 gallons & $10-20 \%$ \\
\hline
\end{tabular}

Liquid-hydrogen storage vessels have been built in sizes ranging from 1 liter laboratory flasks up to 850,000 gallon Dewars. The performance of these storage vessels varies and depends primarily on the type of insulation employed, vessel size and shape, and vessel structural-support considerations. For more information on insulation requirements, see Haettinger, 1966; Perkins and Frainier, 1960; and Ishagoff and Canty, 1964.

Liquefied hydrogen can be transported either by batch lots in Dewars or by continuous or intermittent flow through special piping. Vacuum-insulated containers installed on trucks, trains, barges, or sea-going tankers can be used to transport bulk liquid hydrogen. Although the latter two methods are most cost effective, their use is limited by the scarcity of useful origindestination combinations. Liquid hydrogen barges have been used in the space programs, but no hydrogen tankers have been constructed. Truck and rail shipment of hydrogen are we11-developed technologies and at present are the primary methods for transporting the merchant liquid hydrogen. Because of the ir present widespread use, highway and rail transport will probably expand to meet increased hydrogen use to the year 2000 . 
The proper design of piping transfer systems is critical especially if transporting efficiency is important and/or transfer distance long. A number of problems arise in long transmission lines; pressure and flow surges, large cooldown losses, possible delays in response due to long cooldown times, and thermal-contraction bowing of the line under partial-fill conditions.

A major consideration for the liquid hydrogen transfer lines is the expected steady-state heat transfer through the pipes into the fluid. Besides wasting liquid hydrogen through evaporation, the resulting two-phase flow reduces the carrying capacity of the line due to fluid-density decrease and to flow-resistance increase. For example, Jacobs et al. (1960) have calculated that if $1 \%$ of the liquid hydrogen evaporates in a pressurized-transfer system, the capacity of the line falls to $6 \%$ of the design maximum flow, while if $10 \%$ of the liquid evaporates, the capacity falls to $2 \%$. Thus, it is important to avoid two-phase flow. However, two-phase flow during the cooldown of the pipeline is unavoidable.

Liquid hydrogen boil-off occurs both in the transient and steady-state transfer operations. Unless the system is designed to utilize this boil-off, gaseous hydrogen must be vented and thus lost. A summary of these various losses is shown in Figure 9. These values shown are representative of actual liquid hydrogen handling, transfer, and storage experience.

All methods involving the transportation of $\mathrm{LH}_{2}$ encounter an economic penalty when the user has no need for hydrogen in the liquid form except as a storage convenience. Ideally, the costs of cooling and liquefaction are equivalent to approximately $10 \%$ of the available combustion energy of the hydrogen. However, because of practical thermodynamic limitations and mechanical inefficiencies, the actual energy used is about 25 to $30 \%$ of the hydrogen heating value (Strobridge, 1974).

Solid Hydrides

The most proven solid hydride system to date is the Public Service Electric and Gas hydride-fuel-cell system with electrolytically produced hydrogen. This system operates at 500 psig with hydriding cooling water temperature of $59^{\circ} \mathrm{F}\left(15^{\circ} \mathrm{C}\right)$ and dehydriding heating water temperature of $131^{\circ} \mathrm{F}$ 


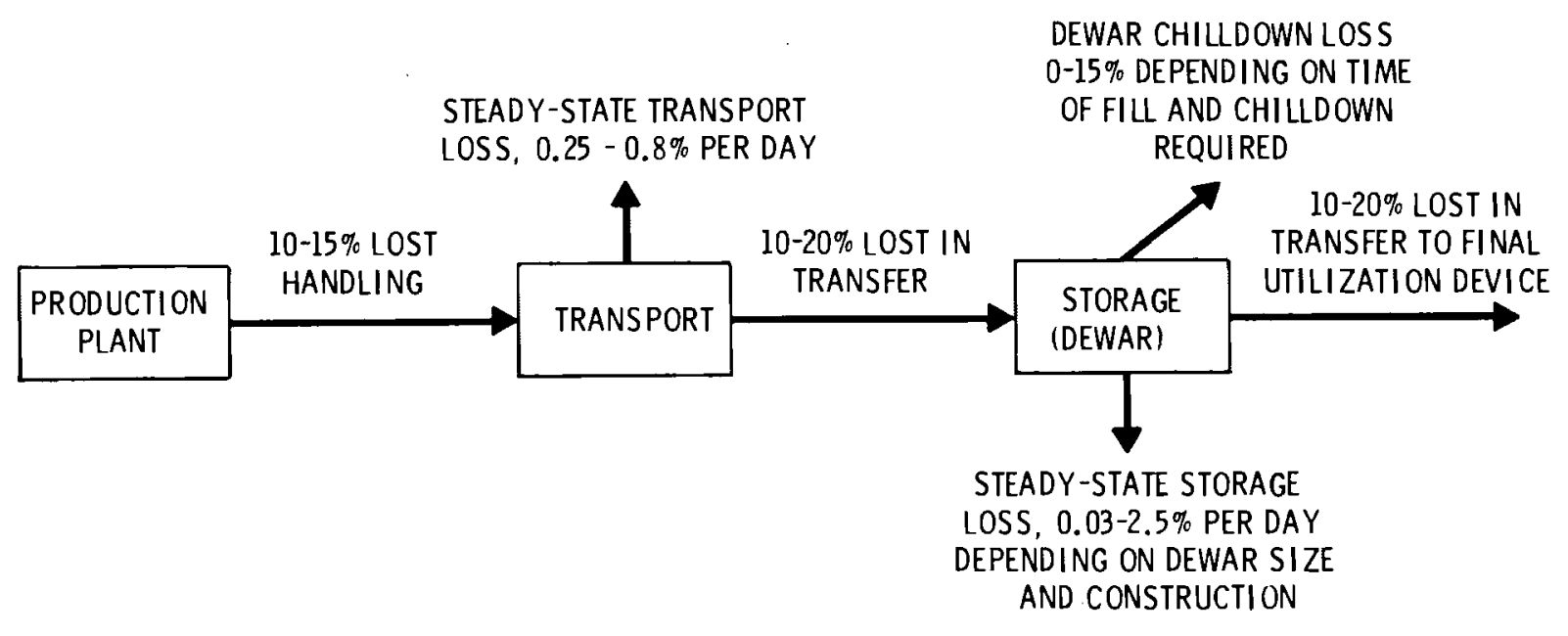

OVERALL LOSSES: 30 TO 70\% + 0.3 T0 3.5\% PER DAY

FIGURE 9. Liquid Hydrogen Losses During Transport, Transfer, and Storage (Cole et al., 1975)

$\left(55^{\circ} \mathrm{C}\right)$. Th is system is a stationary application. If transferred into a vehicular application, this would amount to 65 watt hours per pound of hydride (0.1666 gram cal $/ \mathrm{kg}$ of hydride) which would give a range of $70 \mathrm{miles}$ (112 kilometers) with a 1,000 pound $(454 \mathrm{~kg}$ ) tank at $30 \%$ energy conversion efficiency.

Technical problems associated with the hydride storage are in the areas of heat transfer, deterioration of the hydride bed material, safety, embrittlement of materials used for the containers, and low energy density of storage resulting in weight penalties. None of these problems appear to be serious, although in the area of deterioration of the hydride material, information available is not sufficient to make an accurate determination of the extent of the problem. Low energy density of storage appears to be limiting the application of hydride storage to stationary uses at present.

Heat transfer does not appear to be a serious limiting problem of hydride storage. The rates of hydrogen release and hydrogen absorption during the 
dehydriding and hydriding cycles are dependent upon the overa 11 heat-transfer coefficient in the hydride bed and the temperatures and pressures of operation.

Deterioration of the hydride bed material occurs during the hydriding and dehydriding cycle. Heat rejection and heat addition during the cycle appears to cause the metallic hydride particles to crumble. This tends to reduce the average granular size of the bed and may be a limiting factor in applying new approaches. The extent of this deterioration is unknown at th is time. Accumulated experience with the bed designed and constructed by Brookhaven National Laboratory and being tested at the Public Service Electric and Gas Company, Maplewood Laboratory, will provide additional information relating to th is problem.

In the area of safety, recent information revealed that the pyrophoric property of finely divided metallic hydride particles raises a concern that the operation of a hydride bed may become hazardous (Mathis, 1976). This may also serve to limit design approaches involving higher operating temperatures once more suitable materials become available in an attempt to increase the energy density of storage.

Hydrogen embrittlement of high alloy steels used in hydride storage containers is a common problem. The basic difficulty is the fact that high-strength alloys that the designers choose for fabricating the high stress parts are the most susceptible to hydrogen embrittlement. The data in Table 9 illustrate this point.

Safety

Hydrogen properties frequently mentioned as especially hazardous are the wide combustibility and detonability ranges. The safety of any fue 1 usually requires maintaining the ambient atmosphere below the lower explosive limit. Since the lower explosive limit of hydrogen (4\%) is about that of methane (5\%) and substantially higher than that of gasoline (1\%), hydrogen's explosive characteristics do not make it necessarily more dangerous to handle. Also, the wide range of combustibility is not always detrimental to safety in the handling of hydrogen, particularly in unconfined areas. 
TABLE 9. Relative Degree of Hydrogen-Environment Embrittlement of Classes of Metals (Cole et al., 1975)

Degree of

Embrittlement

Extreme

Severe

Slight

Negligible

\section{Materials}

High strength steels Nickel-base alloys

\author{
Ductile, lower strength \\ steels \\ Pure nickel \\ Titanium alloys
}
Metastable 300 series stainless steels Beryllium-copper Pure titanium

Aluminum alloys Stable austenitic stainless steels Copper
Characteristics

Large decrease in notch strength and notched and unnotched ductility. Some decrease in unnotched strength. Propagation of surface cracks.

Considerable reduction of notch strength and notched and unnotched ductility. No reduction of unnotched strength. Propagation of surface cracks.

Sma 11 decrease in notched strength and unnotched ductility. Failure of unnotched specimens from within.

Essentially unembrittled with no surface cracks.

Compared to natural gas, hydrogen is much more prone to leaks (even through air-tight fittings), can be ignited by very low energy sources (even by invisible static sparks), and is flammable over a very wide range of hydrogen-air mixtures. In liquid form, its extremely low temperature (20 K) can condense any air that comes in contact with it, its tank, or lines. This produces fire and explosion hazards. Furthermore, a hydrogen-oxygen flame is invisible and a hydrogen-air flame is almost invisible in daylight.

Even though hydrogen is more prone to leaks than any other gas, it may never reach a concentration sufficient to sustain ignition because the leak will diffuse so rapidly. Since hydrogen is only one-fourteenth as dense as air, any leaks or spills will rapidly disperse. On the other hand, gasoline, 
propane, or fuel oil vapors are heavier than air and tend to concentration around a leak. Even natural gas diffuses only about one-third as rapidly as hydrogen.

Ordinary flames such as those from hydrocarbons release a great deal of radiant heat, while a hydrogen flame produces relatively little. This is potentially an advantage since fire fighters could work closer to the flame, but precautions must be taken in fighting hydrogen fires because the flame is so nearly invisible.

An analysis of accidents involving hydrogen shows that this material has been used quite safely and would certainly not disqualify it from future use on a wider scale. However, it should be realized that the hydrogen users up to now were primarily a few government contractors and well-managed, experienced, large commercial suppliers and refineries. When a technology is carefully controlled, a high level of safety is maintained with little additional control from regulatory bodies. The more widespread the use of this potentially dangerous material, the greater the need for controls and reviews.

The "Hindenburg Syndrome" is a term widely used to indicate public identification of hydrogen as a dangerous substance. The literature on hydrogen is replete with references to the 1937 explosion of the German dirigible, Hindenburg. Hydrogen fuel is also associated with the hydrogen bomb. Public attitudes toward the wide spread use of hydrogen as fuel could possibly create difficulties in establishing the required transportation system.

DOE is currently conducting a risk analysis of hydrogen transport. It will be necessary to show that hydrogen dangers can be met and that safety standards can obtain acceptable risk levels. Conventional public education and public relation methods could be used to transfer this information.

\section{Regulations}

The primary national regulations applicable to hydrogen transportation are contained in the Code of Federal Regulations (CFR), Title 49, Transportation. Appendix F lists sections in the CFR related to bulk hydrogen 
transportation. Most of these regulations are general and apply to hazardous materials without specific reference to hydrogen or consideration of problems unique to hydrogen. CFR provides specifications for containers used in rail and highway transportation of compressed hydrogen. The tank car specifications list specific materials, design, and welding requirements. Regulations on filling and manifolding of hydrogen containers are provided by the CFR. Regulations for gaseous hydrogen pipeline transmission are indirectly covered under 49 CFR, Parts 100-199. This safety standard is written for natural gas distribution lines but would also cover hydrogen transmission. However, the regulations were not drafted with hydrogen in mind.

Title 49 in the CFR may need to be expanded to incorporate standards specific to hydrogen. However, new codes and standards may also be needed for large-scale hydrogen use. National committees formed by concerned user groups (ASME, ANSI, ASTM, NFPA, API) may be required to establish these needs and develop the required codes and standards. 


\section{REFERENCES}

American Gas Association, 1977a, Commercializing High-BTU Coal Gasification: The Rationale for Immediate Action.

American Gas Association, 1977b, Gas Facts 1976 Data.

Amercian Waterways Operators, Inc., 1973, Big Load Afloat: U.S. Domestic Water Transportation Resources.

Arthur D. Little, Inc., 1974, A Model Economic and Safety Analys is of the Transportation of Hazardous Substances in BuIk. Prepared for U.S. Department of Commerce, Maritime Administration, Office of Domestic Shipping.

Bradley, W. H., 1931, Origin and Microfossils of the 0il Shale of the Green River Formation of Colorado and Utah. USGS Professional Paper 168.

Braunstein, H. M., E. D. Copenhaver, and H. A. Pfuderer, 1977, Environmental, Health, and Control Aspects of Coal Conversion: An Information Overview. ORNL/EIS-94, Volume I.

Bureau of Mines, 1977, Crude $0 i 1$ and Refined Products Pipeline Mileage in the U.S.

Cameron Engineers, Inc., 1978. Quarterly Report. Synthetic Fuels. March.

Cole, R. B., R. S. Magee and J. W. Hollenberg, 1975, Hydrogen Storage and Transfer. AD-A016 256.

Committee on Future Energy Prospects, 1977, Synfuels. National Petroleum Council, Report of Analytical Group, Topic No. 21.

Cornei1, H. G., F. J. Heinzelmann and E. W. S. Nicholson, 1977, Production Economics for Hydrogen, Ammonia and Methanol During the 1980-2000 Period. CONF-761134, pp. 53-58.

Coughlin, W. J. (ed.), 1978, "Mobil Favors Own Methanol Process and Study for DOE," Coal Technology. August.

Currie, J. W. and D. J. Brown, 1975, The Potential for Producing and Marketing Portable Fuels from Coal for the Transportation Sector. Battelle Energy Program Technical Note.

Department of Energy, 1978a, "EPRI Study Sees 650,000 B/D Liquids-From-Coal by 1995, Up to $\$ 20$ Billion Cost," Inside DOE. March 27.

Department of Energy, 1978b, "Myers Begin Major Assessment of Commercialization for 23 Technologies," Inside DOE. June 5. 
Department of Energy, 1978c, "0il Shale: Company Attitudes 'May be Barrier, " Inside DOE. July 3.

Department of Energy, 1978d, "Utilities Support Liquefaction Speedup Concept, Quick Move on SRC-II," Inside DOE. March 20.

Department of Energy, 1978e, "Commercialization Impact: DOE/RA, Task Force Assess Market Penetration," Inside DOE. September 11.

DeSteese, J. G., S. B. Ahlstrom, K. A. Baumgart, A. C. Campbe11, G. W. Dawson, C. A. Geffen, P. L. Hendrickson, H. E. Lippek, and W. Wakamiya, 1978, Energy Material Transport, Now through Year 2000, System Characteristics and Potential Problems - Task 3 - Progress Report - Petroleum Transportation.

PNL-2421.

DeSteese, J. G. and C. A. Geffen, 1978, Energy Material Transport, Now Through Year 2000, System Characteristics and Potential Problems - Task 4 - Progress Report - Natural Gas Transportation. PNL-2422.

Dupree, W. G. and J. S. Corsentino, 1975, United States Energy Through the Year 2000 (Revised). Bureau of Mines.

Edeskuty, F. J. (Comp.), 1978, Critical Review and Assessment of Problems in Hydrogen Energy Delivery Systems. LA-7405-PR.

Exxon Company, U.S.A., 1977, Energy Out look 1977-1990.

Foster Associates, Inc., 1977, Fuel and Energy Price Forecasts. EPRI EA-411, Volumes I and II.

Fuel Task Group on Coal Availability, 1973, U.S. Energy Outlook - Coal Availability. National Petroleum Council.

Gregory, D. P., 1972, A Hydrogen Energy System. Institute of Gas Technology. Haettinger, G. C., 1966, "Considerations in the Design, Selection, and Use of Vacuum Insulated Pipe," Advances in Cryogenic Engineering. 11:98.

Hinkle, F. J. and G. J. Foley (Project Officers), 1976, Impacts of Synthetic Liquid Fuel Development. Volumes I and II, Stanford Research Institute.

Howard-Smith, I. and G. J. Werner, 1976, Coal Conversion Technology. Chemical Technology Review No. 66.

Ishagoff, I. and J. M. Canty, 1964, "Quilted Insulation," Advances in Cryogenic Engineering. $\underline{9}: 45$. 
Jacobs, R. B., R. J. Richards and S. B. Schwartz, 1960, "The Transfer of Liquefied Gases," Advances in Cryogenic Engineering. 1: $1: 87$.

Johnson, J. E., 1972, The Storage and Transportation of Synthetic Fue1s. Union Carbide Corporation.

Johnson, J. E., 1978a, Broadening the Domestic Base for Feedstocks: Petroleum Versus Coal. Union Carbide Corporation.

Johnson, J. E., 1978b, "Not Ready to Pour on the Coal," Chemical Week. $122(19): 62-64$.

Kelley, J. H., 1975, Hydrogen Tomorrow, Demands and Technology Requirements. JPL-5040-1.

Maritime Administration and U.S. Coast Guard, 1974, U.S. Tank Barge Study.

Mathis, D. A., 1976, Hydrogen Technology for Energy. Noyes Data Corporation.

McGraw-Hi11 (pub1.), 1978, "DOE Study Sees Environmental Concerns Delaying New Coal Technologies," Coal Daily. September 8.

Perkins, W. E. and R. J. Frainier, 1960, "Practical Storage and Distribution of Liquid Hydrogen and Helium," Advances in Cryogenic Engineering. 5:69.

Petroleum Publishing Company, 1977, International Petroleum Encyclopedia.

Reynolds, R. A. and W. L. Slager, 1972, Transportation and Storage of Hydrogen for Eco-Energy. GE 72TMP54, General Electric Company.

Richardson, F. W., 1975, 0il from Coal. Chemical Technology Review No. 53.

Rothberg, P. F., 1978a, Coal Gasification and Liquefaction. Congressional Research Service, Major Issues System, March 13.

Rothberg, P. F., 1978b, 0il Shale Development: Outlook Current Activities and Constraints, Library of Congress, Congressional Research Service, March 29.

Salzano, F. J. and C. Braun (eds.), 1977, Hydrogen Energy Assessment. BNL -50807 .

Schiefelbein, G. F., L. K. Mudge, R. J. Robertus and G. E. Stegan, 1977, Preliminary Feasibility Study of Four Selected Coal Conversion Processes for 0aklands Coal. Pacific Northwest Laboratory.

She 11 0i1, 1976, The National Energy Out look 1980-1990.

Stanford Research Institute, 1977, Fuel and Energy Price Forecasts. EPRI EA-433, Volumes I and II. 
Strobridge, T. R., 1974, Cryogenic Refrigerators - An Updated Survey. U.S. Department of Commerce, Nationa 1 Bureau of Standards, U.S. Technical Note 655. Synthetic Fuel Pane1, 1972, Hydrogen and Other Synthetic Fuels. Prepared for the Federal Council on Science and Technology $R$ and D Goals Study, TID-26136.

Warren, I. H., 1976, "Fuels from Coal - Choices in Technology," Coal Miner. December, pp. C9-C12.

Wei1, K. H., 1972, Trip Report on Hydrogen Technology in Germany. A Report to the National Academy of Science, Commission on Motor Vehicle Emission, Alternative Power Systems.

Wurm, J. and R. F. Pastris, 1973, The Transmission of Gaseous Hydrogen. SPE4526. 


\section{$\underline{\text { BIBLIOGRAPHY }}$}

Cameron Engineers, Inc., 1977, Synthetic Fuels. Vol. 14, No. 2.

Cameron Engineers, Inc., 1978, Synthetic Fue1s. Vo1. 15, No. 1.

Code of Federal Regulations, 1976, Coast Guard, Department of Transportation. Title 46, General Services Administration, Washington, DC.

Code of Federal Regulations, 1976, Navigation and Navigable Waters. Title 33, General Services Administration, Washington, DC.

Code of Federal Regulations, 1976, Transportation. Title 49, General Services Administration, Washington, DC.

"Department of Energy Organization Act," Public Law 95-91, August 4, 1977.

Harte, J. and M. El-Gasseir, 1978, "Energy Use and Water," Science. Vol. 199, No. 4329.

Huebler, J., 1975, "Gasification and Liquefaction of Coal," Coal Mining

Journal. Vol. 61, pp. 16-23.

Interstate Commerce Commission, 1978, In the Public Interest.

Li, C. T., G. A. Jensen, and G. F. Schiefelbein, 1974, A Survey of Processes for the Liquefaction and Solvent Refining of Coal. Battelle Research Report.

Miche11, J. W., 1973, Hydrogen and Synthetic Fuels for the Future. American Chemical Society.

Mudge, L. K., G. F. Schiefelbein, C. T. Li, and R. H. Moore, 1974, The Gasification of Coal. A Battelle Energy Program Report.

Perry, H., 1974, "Coal Conversion Technology," Chemical Engineering. Vol. 81, No. 15 , pp. 88-102.

Schiefelbein, G. F. and L. K. Mudge, 1974, Coal Gasification: A State-of-theArt Review. Battelle Research Report.

Segal, M. R., 1978, Alcohol Fuels: Methanol, Ethanol, Gasahol. Congressional Research Service, Major Issues System, April 13. 

APPENDIX A 
COMMERCIAL PROJECTS

\section{c-b Shale 0 il Venture}

Participants: Ashland 0il, Occidental $0 i 1$ Shale. Original partners, ARCO and TOSCO withdrew in 1975. A third original partner, Shel1, withdrew and Occidental joined (with Ashiand as remaining partner) in 1976.

Location: Federal tract $\mathrm{C}-\mathrm{b}$ in Piceance Creek basin, Colorado

Technology: Vertical modified in situ.

Schedule/Cost: Full-scale facility operations by September 1982 with capital investment of $\$ 445$ million.

Production Estimate: Occidental plans 57,000 b/d by September 1983 but actual production of $30,000 \mathrm{~b} / \mathrm{d}$ or less appears more probable at this time.

Factors Affecting Development: Lawsuit (potential one-year delay); permits (no major delays foreseen); questionable economics of extraction; groundwater; restabilization of retorts; off-gas disposition; raw-shale distribution.

Colony Development Operation

Participants: Tosco Corporation, ARCO, Ashland, Shell.

Location: Colony Dow West Property near Grand Valley, Colorado.

Technology: Surface or above ground.

Schedule/Cost: Schedule depends on incentives. ARCO says it would support $25-30 \%$ of the $\$ 1.132$ billion project if a productionoriented incentive is approved. It would seek partners and obtain permits to start construction in 1980, with completion slated by December 1983 .

Production Estimate: $47,000 \mathrm{~b} / \mathrm{d}$

Factors Affecting Development: Construction plans at a stand-still since October 1974 pending initiation of federally sponsored synfuels incentive program; small land exchange; price of $0 i 1$; permits; rate of recovery. 
Multi-Mineral and Shale 0il Production

Participant: Superior $0 i 1$ Company of Houston.

Location: 6,500 acre of privately owned tract in Piceance Creek basin near Meeker, Colorado.

Technology: McDowell/Wellman circular traveling grate retort.

Schedule/Cost: Commercial plant to produce 13,000 b/d could be in operation in five years assuming land exchange with federal government. Estimated cost is $\$ 300$ million.

Production Estimate: $0 i 1-13,000 \mathrm{~b} / \mathrm{d}$; nahcolite - 4,500 tons/day; cell grade alumina - 700 tons/day; soda ash - 15,000 tons/day.

Factors Affecting Development: Scale-up problem; economics of a complex process; mining deep formation; marketability of large quantities of nahcolite; land exchange.

Occidental oil Shale, Inc.

Participant: Occidental $0 i 1$ Shale.

Location: Logan Wash site near De Beque, Colorado.

Technology: Vertical modified in situ.

Schedule/Cost: A 53-month project through mid-FY-81 in two phases. First to assess two specific retort designs; then to test the selected design for technical feasibility. Total expected cost of $\$ 60.5$ million.

Production Estimate: No specific commercial project planned.

Factors Affecting Development: $0 i 1$ shale underlying the tract averaged 1015 gallons/ton; applicability to richer deposits needs to be tested; resources on site will limit production to maximum $5,000 \mathrm{~b} / \mathrm{d}$. 
Rio Blanco 0 il Shale Company

Participants: Gulf 0il, Standard of Indiana.

Location: Federal trace C-a in Piceance Creek basin, Colorado.

Technology: Vertical modified in situ and surface retorting.

Schedule/Cost: Capital cost for modular phase of modified in situ activity is estimated at $\$ 93$ million. Five or more retorts are scheduled for completion by 1982. Five and a half year demonstration is planned for Lurgi surface module.

Production Estimate: 50,000 to $76,000 \mathrm{~b} / \mathrm{d}$ from modified in situ retorts and surface retorts by 1987 .

Factors Affecting Development: Lawsuit (potential one year delay); permits; technology needs to be demonstrated; groundwater, restabilization of retorts; off-gas disposition; raw-shale disposition; funding of community facilities; funding of surface module.

Tosco Sand Wash Project

Participant: Tosco Corporation.

Location: 14,688 acres of state leased land in Sand Wash area of Uinta basin near Vernal, Utah.

Technology: Surface and modified in situ.

Schedule/Cost: Proposed 75,000 b/d project costing approximately $\$ 1$ billion.

Production Estimate: No projection.

Factors Affecting Development: Economics and mining feasibility; utilization of resources; extraction economics; water resources; development in remote harsh environment. 
Union B Shale 0il Production

Participant: Union $0 i 1$ Company (California)

Location: 22,000 acres of fee land near Grand Valley, Colorado.

Technology: Underground room-and-pillar mining and surface retorting.

Schedule/Cost: Suspended plans for commercial project ranging in size from 50,000 to $150,000 \mathrm{~b} / \mathrm{d}$. Suspension relates to uncertain economics and lack of federal incentives. Current plans are to build a $\$ 100$ million commercial module of $7,200 \mathrm{~b} / \mathrm{d}(10,000$ ton/day) if $\$ 3 / \mathrm{bbl}$ shale $0 i 1 \mathrm{tax}$ credit is approved.

Production Estimate: 7,000 b/d by 1985; 30,000 b/d by the year 2000 .

Factors Affecting Development: Scale-up; water consumption, uncertain economics.

White River Shale Project

Participants: Sohio Petroleum Company, Sunoco Development Company, Phillips Petroleum.

Location: Federal tracts $U-a$ and $U-b$ in Uinta basin near Bonanza, Utah.

Technology: Surface and modified in situ.

Schedule/Cost: 1976 cost estimate for $100,000 \mathrm{~b} / \mathrm{d}$ plant was $\$ 1.2$ billion but schedule is held up pending outcome of lawsuit on land ownership.

Production Estimate: $100,000 \mathrm{~b} / \mathrm{d}$.

Factors Affecting Development: Lawsuit (indefinite delay); permits; questionable extraction economics; funding of community facilities. 
DEMONSTRATION, PILOT, OR RESEARCH PROJECTS

Dow Shale Gas Production

Participant: Dow Chemical

Location: 80-acre site belonging to Dow in Michigan Basin.

Technology: True in situ.

Schedule/Cost: Four-year contract for $\$ 14$ million awarded by ERDA in March 1977 for production of fuels from Antrim oil shale formation.

Production Estimate: Unknown.

Factors Affecting Development: Unproven technology; not ready for scale-up.

Equity Shale 0 il Production

Participant: Equity $0 i 1$ Company (Salt Lake City)

Location: One-acre site in the Piceance Creek basin of Colorado.

Technology: Solution mining; modified in situ.

Schedule/Cost: DOE contributes $86 \%$ of $\$ 6.5$ million project, expected to last 55 months.

Production Estimate: Unknown.

Factors Affecting Development: Limited resource in private sector, unproven technology; lack of strong private commi tment. 
Geokinetics Shale 0 il Production

Participants: Geokinetics, Inc., Aminoil USA.

Location: State leased tract in Uintah County near Vernal, Utah.

Technology: Horizontal modified in situ.

Schedule/Cost: Five-year project will cost $\$ 9.1$ million with DOE providing $\$ 5.9$ million.

Production Estimate: Current production is 200-400 barrels per month with a target of 2,000-5,000 b/d on four sections now under state lease.

Factors Affecting Development: Limited resource; scale-up.

Getty 0 il Production by Mining

Participant: Getty $0 i 1$.

Location: Getty property in the Piceance Basin of Colorado.

Technology: Surface thermal extraction using a Lurgi-Rhurgas device.

Schedule/Cost: No schedule for operations.

Production Estimate: Single Lurgi retort - 3,600 tons/day. Retorts would be combined into 50,000-100,000 b/d plants. Getty could support 2-3 such plants in Piceance Basin.

Factors Affecting Development: Completion of test on diatomaceous earth; completion of oil shale evaluation; proof of economics; funding of plants and support facilities; funding of community facilities; permits. 
IGT Shale 0 il Production

Participants: Institute for Gas Technology for the gas industry through the American Gas Association.

Location: Pilot plant located in Chicago.

Technology: Surface IGT hydroretorting.

Schedule/Cost: Proposed $71 / 2$ year research and development program with first year costs of $\$ 2.7$ million.

Production Estimate: Resource is estimated to support 1,000 plants producing $50,000 \mathrm{~b} / \mathrm{d}$.

Factors Affecting Development: IGT has not been successful in obtaining government support.

Laramie Energy Research Center

Participants: Laramie and Rocky Mountain Energy Company.

Location: Near Rock Springs, Wyoming.

Technology: Modified in situ.

Schedule/Cost: Undetermined cost.

Production Estimate: Unknown.

Factors Affecting Development: Site 9 had low oil recoveries. Site 12 was to have been explosively fractured in August 1977 but explosives failed to detonate. 
MECCO, Inc.

Participant: MECCO

Location: Land leased from Sohio (Section 6, T10S, R25E, SLM) in Uinta basin near Bonanza, Utah.

Technology: In situ, drilling followed by injection of a small amount of fuel and oxidant and retorting in a manner similar to fire flood operation. All retorting will occur at least $200 \mathrm{ft}$ underground.

Schedule/Cost: Cost and scale have not been released. Planning and engineering underway.

Production Estimate: No estimate available.

Factors Affecting Development: Most details are confidential and not available.

Paraho Retort Development

Participant: Paraho Development Corp. (Development Engineers, Inc.).

Location: Anvil Points Facility near Rifle, Colorado.

Technology: Surface retort.

Schedule/Cost: Currently under $\$ 3.7$ million contract with the Navy to produce $65,000 \mathrm{~b} / \mathrm{d}$ by mid-1978. Paraho proposes scaleup to handle 11,500 tons/day of $30 \mathrm{gallon} /$ ton shale to yield $7,300 \mathrm{~b} / \mathrm{d}$.

Production Estimate: Unknown.

Factors Affecting Development: Uncertain private funding; EIS. 
Talley-Frac

Participant: Talley-Frac Corp. (Mesa, Arizona).

Location: Wyoming Section 17, T18N, R106W.

Technology. True in situ.

Schedule/Cost: $\$ 3$ million first phase will last 18 months and cover R\&D for rubblizing oil shale and increase product recovery. $\$ 9.3$ million second phase will last about two years with goal of demonstrating capability of producing up to $5,000 \mathrm{~b} / \mathrm{d}$.

Production Estimate: Phase $1-300 \mathrm{~b} / \mathrm{d}$; Phase $2-5,000 \mathrm{~b} / \mathrm{d}$ production from 16 adjacent retorts.

Factors Affecting Development: Technical feasibility of true in situ retorting; no resource in private control; unproven technology.

Westco in situ Demonstration

Participants: Western $0 i 1$ Shale Corp. (operator), A. G. McKee, Amoco, Ashland, Chevron, Cities Service, Getty, Gulf, Mobil, Shel1, and Sun (sponsors).

Location: Uinta basin near Bonanza, Utah.

Technology: Modified in situ.

Schedule/Cost: First phase - planning and cost estimates of three small in situ chimneys in 15 and 30 gallon/ton shale; this first phase cost $\$ 400,000$. Second phase - $\$ 25$ million project is being contemplated for an in situ program.

Production Estimate: Unknown.

Factors Affecting Development: Uncertainity of Federal participation; DOE rejected Wesco's response to an in situ Program Opportunity iNotice.

SOURCE: Synthetic Fuels. Quarterley Report, Cameron Engineers, Inc., March 1978

"Oil Shale: Company Attitudes 'May be Barrier", Inside DOE, july 3, 1978. 


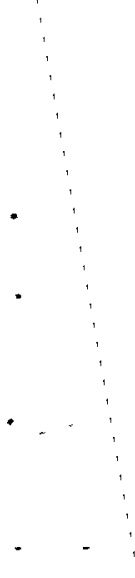


APPENDIX B 
APPENDIX B

TELEPHONE CONTACTS

Name

Mr. Gordon Ange 11

Mr. John Blackburn

Ms. Joan Walsh Cassedy, Director of Information

Mr. Hugh Chaffe, District Supervisor

Ms. Velma Cooper

Mr. Caesar DeLeon, Director

Commander William J. Ecker, Chief

Mr. Morton Freedman

Mr. E. S. Glover

Mr. Manual Gutielliz, Secretary

Mr. Sidney Haynes

Mr. Jeff Hitchings

Mr. Gerald Hurley

Mr. John E. Johnson, Manager
Affiliation

Division of Inland Waterways

Maritime Administration/DOC

Tankers and Barges

American Petroleum Institute

National Petroleum Council

Interstate Commerce Commission

Federal Railroad Administration/DOT

Department of Transportation

Office of Pipeline Safety Regulation

Information and Analys is Staff

USCG/DOT

American Petroleum Institute

Carter $0 i l$ Company

American National Standards Institute

Quality Control Supervisor

Texas Eastern Pipeline Company

American Gas Association

Pipeline Transport

American Petroleum Institute

Feedstock and Energy Policy Union Carbide (New York) 
Name

Mr. David Jones

Mr. Melvin Judah

Mr. Clyde Klinstiver

Mr. Mark Kostalich, Marketing Manager

Mr. Don Kuester

Mr. Jack Ligon, Retired from ARHCO

Mr. John Michael, Rail Chief

Mr. William Miller

Mr. Harold Muth

Mr. William Norris

Mr. Ron Riley, Secretary and Director of Research

Mr. Pau 1 Rothberg

Dr. Frank Salzano

Dr. Benjamin Schlesinger

Mr. J. Glen Seay
Affiliation

Motor, Pipeline and Water Carrier Analys is Department Interstate Commerce Commission

Office of Pipeline Safety Regulation/DOT

Office of Hazardous Materials Operations/DOT

Tank Train Systems

General American Transportation

Corporation

SW Regional Office

Office of Pipeline Safety

Regulation/DOT

Petroleum Consultant

American National Standards Institute

Interstate Commerce Commission

Tank Car and Truck Transport

American Petroleum Institute

American Waterways Operators, Inc.

Rail Carrier Analysis

Interstate Commerce Commission

Association of 0 il Pipelines

SPR Congressional Research Service Library of Congress

Energy Storage and Conversion Division Brookhaven National Laboratory

American Gas Association

Institute of Gas Technology 
Name

Mr. Philip Selle

Mr. Michael Lee Thiele, Project Manager

Mr. James Tuite
Affiliation

Waterborne Commerce Statistics Center Corps of Engineers/DOA

Pipeline Division Bechtel, Inc.

General Counsel

Interstate Commerce Commission 


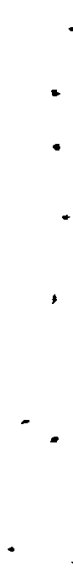


APPENDIX C 


$$
\text { Code of } \frac{\text { REGULATIONS }}{\text { Federal Regulations }}
$$

33 CFR $80-86$

46 CFR $30-40$

46 CFR $150-155$

151

49 CFR $106-169$

107

49 CFR $170-189$

171

172

174
Subchapter D, Navigation Requiremements for Certain In 1 and Waters

Regulations applicable to vessels navigating harbors, rivers and inland waters of the U.S.

Subchapter D, Tank Vessels

Requirements for material, design, construction, inspection, handling, and stowage of cargo and operations of tank vessels.

Subchapter 0, Certain Bulk Dangerous Cargoes

Specifications for tank barge construction, inspection, and certification by USCG, cargo handling, stowage, and transfer.

Subchapter B, Hazardous Materials

Prescribes procedures utilized by MTB and OHMO in carrying out their duties pertaining to the transportation of hazardous materials.

Subchapter C, Hazardous Materials Regulations

General information, regulations, and definitions. Prescribes requirements of DOT governing the transportation of hazardous materials.

Tabulation of hazardous materials for purpose of transportation. It classifies and specifies labeling, packaging, and transportation requirements.

Defines hazardous materials for transportation purposes and prescribes requirements for air, rail, highway, or water shipment.

Additional requirements for transportation of hazardous materials in or on rail cars.

Additional requirements for transportation of hazardous materials by vessels. 
177 Requirements for transporting hazardous materials by motor vehicles.

179 Tank car specifications. Covers general design requirements and specifications for pressure tank car tanks, non-pressure tank car tanks, multi-unit tank car tanks, and liquefied hydrogen tank car tanks.

49 CFR 190-199 Subchapter D, Pipeline Safety

190 Establishes min imum federal safety standards for pipeline facilities and the transportation of gas.

191 Requirements for reporting gas leaks.

192 Minimum safety requirements for pipeline material, design, components, welding, construction, maintenance, operation, and testing.

195 Regulations governing the transportation of liquid hazardous materials, petroleum, and petroleum products by pipeline. This part also includes accident reporting, design requirements, construction, operation and maintenance, and hydrostatic testing.

49 CFR 200-299 Federal Railroad Administration, Department of Transportation

Covers safety standards, operations, rules, and maintenance regulations for railroad tracks, freight cars, and safety appliances. 


\section{PROPERTIES OF HYDROGEN AND METHANE}

\begin{tabular}{|c|c|c|}
\hline & $\mathrm{H}_{2}$ & $\mathrm{CH}_{4}$ \\
\hline Combustion Range, vol\% in air & $4-75$ & $5.3-15.0$ \\
\hline Combustion Range, vol\% in $0_{2}$ & $4-96$ & $5.0-61$ \\
\hline Detonation Range, vol\% in air & $20-65$ & $6.3-13.5$ \\
\hline Detonaton Range, vol\% in $\mathrm{O}_{2}$ & $15-90$ & - \\
\hline Ignition Temperature in Air, $\mathrm{K}$ & 858 & 813 \\
\hline Minimum Ignition Energy in Air, mJ & 0.02 & 0.29 \\
\hline $\begin{array}{l}\text { Minimum Absolute Pressure for Ignition in Air, } \\
\mathrm{cN} / \mathrm{m}^{2} \text { (Torr) }\end{array}$ & $67(50)$ & $69(52)$ \\
\hline Flame Temperature, $\mathrm{K}$ & 2323 & 2148 \\
\hline Flame Velocity, $\mathrm{cm} / \mathrm{s}$ & 270 & 37 \\
\hline Flame Emissivity & 0.10 & 1.0 \\
\hline Quenching Distance (at $1 \mathrm{~atm}$ ), cm & 0.06 & 0.203 \\
\hline Heat of Combustion, $\mathrm{kJ} / \mathrm{g}-\mathrm{mol}$ & 242 & 802 \\
\hline Diffusion Coefficient in Air at $273 \mathrm{~K}, \mathrm{~cm}^{2} / \mathrm{s}$ & 0.63 & 0.16 \\
\hline Electrical Resistivity of $\mathrm{LH}_{2}, \quad-\mathrm{cm}$ & $4.6 \times 10^{19}$ & - \\
\hline Volume Ratio (gas at $1 \mathrm{~atm}$ and $300 \mathrm{~K}$ to $\mathrm{LH}_{2}$ ) & 860 & - \\
\hline $\begin{array}{l}\text { Pressure to Maintain } \mathrm{LH}_{2} \text { Density in Gas at } \\
300 \mathrm{~K} \text {, atm }\end{array}$ & 2000 & - \\
\hline Normal Boiling Temperature of Liquid, $K$ & 20.3 & 112 \\
\hline Volume Latent Heat of Vaporization, J/ & 31700 & - \\
\hline Specific Gravity, $0 \mathrm{C}, 700 \mathrm{~mm} \mathrm{HG}$ & 0.08987 & 0.7169 \\
\hline Molecular Weight & 2.016 & 16.032 \\
\hline
\end{tabular}




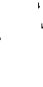

.

-

$\cdot$ 
APPENDIX D 


\section{CFR 172.101 Hazardous Materials Table}

(1)

Hazardous Materials Descriptions and
Proper Shipping Names

$\star \Delta / \mathrm{W}$

Compressed Gas, n.o.s.

Conpressed Gas, n.o.s.

(3)

(4)

(5)

(6)

(7)

\begin{tabular}{|c|c|c|c|c|}
\hline \multicolumn{2}{|c|}{$\begin{array}{l}\text { Maximum Quantity } \\
\text { in One Package }\end{array}$} & \multicolumn{3}{|c|}{ Water Shipments } \\
\hline $\begin{array}{l}\text { (a) } \\
\text { Passenger Carrying } \\
\text { Aircraft or Railcar }\end{array}$ & $\begin{array}{l}(b) \\
\text { Cargo Oniy } \\
\text { Aircraft } \\
\end{array}$ & $\begin{array}{l}\text { (a) } \\
\text { Cargo } \\
\text { Vessel } \\
\end{array}$ & $\begin{array}{l}\text { (b) } \\
\text { Passenger } \\
\text { Vessel }\end{array}$ & $\begin{array}{c}\text { (c) } \\
\text { Other } \\
\text { Requirenents } \\
\end{array}$ \\
\hline Forbidden & $300 \mathrm{lbs}$ & 1 & 4 & \\
\hline $50 \mathrm{lbs}$ & $300 \mathrm{lbs}$ & 1,2 & 1,2 & \\
\hline No Linit & No $L$ iяเіt & 1,2 & 1,2 & \\
\hline $1 \mathrm{qt}$ & $10 \mathrm{gal}$ & 1,2 & 1 & \\
\hline $1 \mathrm{qt}$ & $10 \mathrm{gal}$ & 1,2 & 1 & \\
\hline
\end{tabular}

* Crude 0il, Petroleuni

Combustible Norie liquid

Labels Required

(a) ${ }^{\text {Packaging }}$

(b)
Specific

Hazard Class (if not Accepted)

Exceptions Requirement

Flamiable Flammable Gas

173.306

173.302

173.304
173.305

Gas

173.302

173.304

173.305

Crude 0il, Petroleum

Flammable

Flammable Liquid

$173.118 a$

None

173.119

Flammable Flannable Liquid

173.118

173.119

Methyl Alcohol

Liquid

$(173.190$

"Material may' or may not be regulated under the class shown depending on whether the material meets the definition of the hazard class 1 isted for that entry or not.

\section{PACKAGING}

173.118 - Limited quantities of flamnable liquids.

173.118a - Exceptions for combustible liquids.

173.119 - Flarmable liquids not specifically provided for.

173.3ú2 - Charginy of cylinders with nonl iquified compressed gases.

173.304 - Charging of cylinders with liquified compressed gases.

173.305 - Charging of cylinders with a mixture of compressed gas and other material.

173.306 - Limited quantities of compressed gases.

\section{WATER SHIPMENTS}

1 - "On-deck" stowage.

2 - "Under-deck" stowage.

2. - Both stowages authorized; "under-deck" stowage to be used if space available. Authorized to ve transported only in limited quantities listed in CFR section specified in column 5 and subject to stowage requirenents specified for a 


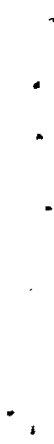


APPENDIX E 


\section{APPENDIX E}

\section{RECENT STUDIES ON HYDROGEN EMBR ITTLEMENT}

Some recent studies on hydrogen embrittlement are listed below:

- Sandia Laboratories Livermore (SLL) is involved in examining critical defect sizes for rapid crack propagation, other aspects of propagation in the presence of hydrogen, and the effects of odorants mixed in hydrogen. SLL is also developing an alloy to improve A516-70 steel ductility in hydrogen and to improve its strength by controlling grain size and distribution of manganese and perlite colonies.

- Professor M. R. Louthan, Jr., at the Virginia Polytechnic Institute, Blacksburg, Virginia, has been performing fundamental investigations of hydrogen embrittlement.

- NASA - Ames Research Center is investigating hydrogen compatibility of materials.

- Lawrence Livermore Laboratory (LLL) is performing theoretical investigations of crack initiation and growth.

- Welding Research Council and American Welding Society are investigating the embrittlement in weldments. 


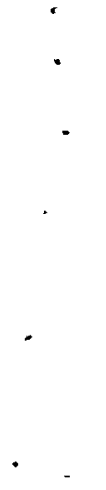




\section{APPENDIX F}


APPENDIX F

FEDERAL REGULATIONS FOR BULK HYDROGEN TRANSPORTATION

GASEOUS HYDROGEN

Railroad Tank Cars

49 CFR 173.31 General regulation for qualification, maintenance, and testing. Applicable to dangerous materials; not hydrogen specific.

49 CFR 173.314 References DOT specifications for various tank car services and gives allowable gas pressures; hydrogen specific.

49 CFR 179.500 Specification DOT-107A covering design and construction of tank car tanks for hydrogen service.

Highway Truck Trailers

49 CFR 173.34 General regulations for qualification, maintenance, and testing of cylinders (and tube trailers). Applicable to dangerous materials; not hydrogen specific.

49 CFR 173.301 General requirements for compressed gas cylinders with specific requirements for manifolding of cylinders in hydrogen service.

49 CFR 173.302 Specifies allowable filling limits for compressed gas cylinders. Contains hydrogen specific information.

49 CFR 177.323 Gives requirements for marking truck trailers and tractors.

49 CFR 178.36

Specification for design and fabrication of seamless stee 1 compressed-gas cylinders with over 1000-1b water capacity. The $3 A X$ and $3 A A X$ cylinders are used for hydrogen service.

Pipeline

49 CFR 190 Safety standard for pipeline transmission of gases. Developed for natural gas pipelines. Contains no hydrogen specific information. Includes state standards as reference material. 
Pipeline (contd)

49 CFR 191

Reporting of leaks for gas pipelines. Developed for natural gas pipelines. Not hydrogen specific.

49 CFR 192

Defines minimum standards for materials, design, fabrication, operation, and maintenance of pipelines for natural and other gases. The regulations are designed primarily for natural gas pipelines. LNG is considered briefly (a new standard for LNG facilities has been issued for comment; see Federal Register, 20766-99, Vol. 42, No. 77). CFR 192 does not consider problems or concerns related to hydrogen service. 52 ANSI, API, ASME, ASTM, MSS, and NFPA standards are listed and incorporated by reference.

Cargo Vessels and Trainships

46 CFR 146.24 Allowed transport of cylinders on cargo vessels only and railroad tank cars on trainships only. Regulation deleted in 1975 (see 41 FR 28122). Containers must meet appropriate regulation for tank cars and truck trailers. Present regulations unknown.

Consumer Hydrogen Systems

29 CFR 910.103(b) OSHA requirements for design and location of consumer systems handling gaseous $\mathrm{H}_{2}$. References specific codes to be followed and requirements for isolation of hydrogen handling systems from other structures or occupied areas.

LIQUID HYDROGEN

Railroad Tank Cars

49 CFR 17.3 .316

Defines allowable container specification, pressure, and filling densities for hydrogen tank cars.

49 CFR 179.400

Specification for design and fabrication of liquid hydrogen tank cars (113A 60W-2).

49 CFR 179.401 Specifies design parameters for 49 CFR 179.400. 
Highway Truck Trailers

49 CFR 173.33 General material on authorization of containers for transportation of hazardous material. Provides for "special authorization" under which liquid hydrogen tank trucks are permitted to operate.

49 CFR 177.323 Gives requirements for marking truck trailers and tractors.

Pipeline

49 CFR 190

49 CFR 191

49 CFR 192

See gaseous hydrogen pipelines. Although not specifically mentioned, $\mathrm{LH}_{2}$ would be included under these sections similar to $L N G$. Requirements for $\mathrm{LH}_{2}$ facilities will likely parallel draft safety standards for LNG facilities.

Cargo Vessels and Trainships

46 CFR 146.24 Shipment of $\mathrm{LH}_{2}$ by water was not allowed under these regulations. Regulation deleted in 1976 (see 41 FR 28122). Present regulations unknown. Shipment by barge is allowed by United States Coast Guard under special permit.

Air Transport

14 CFR 103.7

Shipment of $\mathrm{LH}_{2}$ by air was not allowed under these

14 CFR 103.9 regulations. Regulations deleted in 1976 (see 41 FR 15972). Present regulations unknown.

Consumer Hydrogen Systems

29 CFR 1910.103(c) OSHA requirements for design and location of consumer systems handling liquid $\mathrm{H}_{2}$. References specific codes to be followed and requirements for isolation of

hydrogen systems from other structures or occupied areas. 


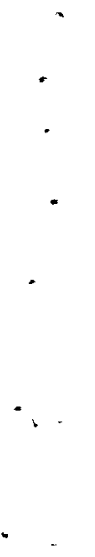




\section{$\underline{\text { DISTRIBUTION }}$}

No. of

Copies

OFFSITE

A. A. Churm

Chicago Patent Group

9800 South Cass Avenue

Argonne, IL 60439

27 DOE Technical Information Center

M. Gottlieb

Division of Environmental

Control Technology

Department of Energy

Washington, DC 20545

R. F. Garrison

Division of Environmental Control Technology

Department of Energy

Washington, DC 20545

C. Grua

Division of Environmental

Control Technology

Department of Energy

Washington, DC 20545

J. A. Sisler

Division of Environmental

Control Technology

Department of Energy

Washington, DC 20545

Richard T. Alpaugh

Transportation Energy Conservation

Department of Energy

Washington, DC 20545
No. of

Copies

Dave Anderson

Transportation Systems

Center

Department of Transportation

Cambridge, MA 02142

R. Ayers

Battelle Memorial Institute

Columbus Laboratories

$505 \mathrm{King}$ Avenue

Columbus, $\mathrm{OH} 43201$

F. L. Balbach

Transportation Planner

Frederick R. Harris, Inc.

Lake Success, NY 11040

C. D. Barton

Transportation Analyst

R. L. Banks Associates

900 17th Street N.W.

Washington, DC 20006

Lana Batts

National Tank Truck Carriers

1616 P Street N.W.

Washington, DC 20036

W. A. Brobst

The Transport Environment

P.0. Box 701

Riverdale, MD 20840 
No. of

Copies

Kenneth Biglane

Director of National

Contingency $\mathrm{Plan}$

Environmental Protection Agency

401 M Street S.W.

Washington, DC 20460

Mr. John Blackburn

Tankers and Barges

American Petroleum

Institute (API)

Washington, DC 20555

Beth S. Blanck

Department of Energy

12th and Penn Avenue N.W.

Washington, DC 20000

Ludwig Brenner

National Transportation

Safety Board

Room 825B

800 Independence Avenue

Washington, DC 20594

Joan Walsh-Cassidy

National Petroleum Council

$1625 \mathrm{~K}$ Street N.W.

Suite 601

Washington, DC 20006

Hugh Chaffe, District

Supervisor

Interstate Commerce Commission

858 Federal B1dg.

915 2nd Avenue

Seattle, WA 98104

Craig Chase

Department of Allocation

Federa 1 Energy

Administration

915 Second

Seattle, WA 98104
No. of

Copies

K. G. Cloninger

She 110 il Company

P.0. Box 2099

1102 Two Shell Plaza

Houston, TX 77001

R. G. Christensen

Program Manager for Market Analys is

Maritime Administration

Washington, DC 20230

Velma Cooper

Federal Railroad

Administration

Room 4414

2100 2nd Street S.E.

Washington, DC 20590

Ed Cygan

Department of Transportation

Office of Pipeline Safety

Regulation

Materials Transportation

Bureau

2100 Second Street S.W.

Washington, DC 20590

J. L. Dale

Association of American

Railroads

1920 L Street N.W.

Washington, DC 20036

Cesar DeLeon

Department of Transportation

Office of Pipeline Safety

Regulation

Materials Transportation

Bureau

2100 Second Street S.W.

Washington, DC 20590 
No. of

Copies

D. C. Diamond

Program Policy Specialist

Department of Energy

FED 3453

Washington, DC 20024

Mel Doernhoufer

Public Relations

Army Corps of Engineers

Saint Louis District

210 North 12 th

St. Louis, M0 63101

C. W. Draffin

Planning and Evaluation U.S. Department of Energy

20 Massachusetts Avenue N.W.

Washington, DC 20545

F. J. Edeskuty

Los Alamos Scientific

Laboratory

MS - 764

P.0. Box 1663

Los Alamos, NM 87545

William Fletcher

Federal Railroad

Administration

Room 4414

2100 2nd Street S.E.

Washington, DC 20590

Ken Fisch 1

Bulk Products

Union Tank Car Company

111 West Jackson Boulevard

Chicago, IL 60604

Alex Gakner

Department of Energy

Washington, DC 20545
No. of

Copies

J. S. Gardenier

U.S. Coast Guard Sponsor

Liaison Representative

U.S. Coast Guard (G-DIST-2/62)

Washington, DC 20590

E. Scott Glover

Carter 0il Co.

P.0. Box 2180

Houston, TX 77001

E. W. Gregory

Transportation Program

Office of Conservation and

Solar Energy

Department of Energy

Washington, DC 20461

Manual Gutiellez

American National Standards

Institute (ANSI)

345 East 47 th Street

New York, NY 10017

Sidney Haynes

Texas Eastern

Pipeline Products Co.

P.0. Box 2521

Houston, TX 77001

Mr. Gerald Hurley

Pipeline Transport

American Petroleum

Institute (API)

Washington, DC 20037

Jeff Hitchings

AGA

1515 Wilson Blvd

Arlington, VA 22209

Brad Holloman

Office of Technology

Asses sment

U.S. Congress

Washington, DC 20510 
No. of

Copies

Donald Igo

Transportation Research

Department of Transportation

400 7th Street S.W.

Washington, DC 20590

John Jimison

Library of Congress

Congressional Research Service

First and Independence S.E.

Washington, DC 20540

Steve Johnson

General Assignment Reporter

Seattle Post Intelligencer

6 th and Wall

Seattle, WA 98121

David Jones

Motor Pipeline and Water

Carrier Analysis

Interstate Commerce

Commission

Washington, DC 20423

Frank King

Public Relations

Army Corps of Engineers

District Engineers Office

319 S.W. Pine

Portland, OR 97204

Clyde $\mathrm{Kl}$ inestiver

DOT, Office of Hazardous

Materials Operations

Materials Transportation

Bureau

DMT 412

2100 2nd St. SW

Washington, DC 20590

Marcus S. Kostolich

General American

Transportation, Inc.

120 South Riverside Plaza

Chicago, IL 60606
No. of

Copies

Don Kuester

SW Regional Office, DOT

Office of Pipeline Safety

Regulation

6622 Hornwood Drive

Houston, TX 77074

Jack Ligon

American National Standards

Institute (ANSI)

P.0. Box 744

Independence, KS 67301

Henry E. Lippek

612 Pioneer Building

600 First Avenue

Seattle, WA 98104

Edward Margolin

8500 Freymand Drive

Chevy Chase, MD 20015

D. P. Maxfield

Nonhighway Transport Systems and Special Projects

Department of Energy

20 Massachusetts Avenue N.W.

Washington, DC 20545

Joseph H. McCann

National Transportation

Policy Study Commission

1750 K Street N.W. - Suite 800

Washington, DC 20006

Joseph J. Merge 1

Department of Transportation, Transportation Systems Ctr. Kenda 1 Square

Cambridge, MA 02142 
No. of

Copies
No. of

Copies

Bill Miller

American Petroleum Institute

2101 L Street N.W.

Washington, DC 20037

Stuart Moges

General American

Transportation, Inc.

120 South Riverside Plaza

Chicago, IL 60606

Harold Muth

Industry and Government

Relations

American Waterways Operators

1600 Wilson Boulevard

Suite 1101

Arlington, VA 22209

William Norris

ICC Rail Carrier Analysis

Washington, DC 20423

Robert Nutter

Office of Transportation

Planning

Department of Transportation

Washington, DC 20590

John O'Connel

Office of Hazardous Materials

2100 Second Street S.W.

Washington, DC 20590

Harvey C. Paice

Maritime Research Board

National Academy of Sciences

2101 Constitution Avenue N.W.

Washington, DC 20418

Gordon 0. Parrish

Interstate Commerce

Commission

Room 5380

Washington, DC 20423
Barbara F. Phillips

Energy Transportation

Systems, Inc. (ETSI)

1620 Eye Street N.W.

Suite 703

Washington, DC 20590

Bob Presley

Office for Emergency

Preparedness

Department of Interior

C Street between 18th and

19th Street N.W.

Washington, DC 20240

Jack H. Rider

Exxon Research and

Engineering Company

Box 101

Florham Park, NJ 07932

Don Riley

Association of $0 i 1$ Pipelines

$1725 \mathrm{~K}$ Street N.W.

Suite 1208

Washington, DC 20006

R. E. Riley

Electric Power Research Institute

3412 Hillview Avenue

Palo Alto, CA 94305

H. A. Roberts

Pipeline Contractors Association

2800 Repub 1ic National Bank Bldg.

Dallas, TX 75201

R. A. Robinson

Battelle Memorial Institute

Columbus Laborator is

505 King Ave.

Columbus, $\mathrm{OH} 43201$ 
No. of Copies

A. Rosenbaum

National Tank Truck Carriers

1616 P. Street N.W.

Washington, DC 20036

Paul Rothberg

SPR Congressional Research

Service (CRS)

Library of Congress

Washington, DC 20555

Frank Salzano

Energy Storage and

Conversion Division

Brookhaven National Laboratory

Long Island, NY

Dr. Benjamin Schlesinger

American Gas Association (AGA)

1515 Wilson Blvd

Arlington, VA

A. L. Schmieg

National Transportation Safety Board

800 Independence Avenue

Washington, DC 20594

John Schuler

Coal Utilization Program

Department of Energy

Washington, DC 20545

H. Seamon

Transportation Research Board

National Research Council

2101 Constitution Avenue

Washington, DC 20418
No. of

Copies

R. B. Smith

Battelle Memorial Institute

Columbus Laboratories

505 King Ave.

Columbus, $\mathrm{OH} 43201$

Susan C. Strauss

Department of Energy

12th and Penn Ave., N.W.

Washington, DC 20461

Paul S. Souder, Jr.

Economics and Systems Dept.

General Research Corp.

7655 01d Springhouse Road

McLean, VA 22101

Dan Sullivan

Department of Transportation, Transportation Systems Ctr. Kendall Square

Cambridge, MA 02142

Mr. M. L. Thiele

Bechtel Power Corp.

Del Monte Tower

5575 De 1 Monte Dr.

Houston, TX 77001

Hugh Thompson

Battelle Memorial Institute Washington Operations 2030 "M" Street N.W. Washington, DC 20545

Stephen Thompson

Analyst in Transportation

Library of Congress - CRS-E

Washington, DC 20540

Jack Wagner

Office of Contingency Planning

Federal Energy Administration

12th St. and Pennsylvania

Ave. N.W.

Washington, DC 20461 
No. of

Copies

$$
\begin{aligned}
& \text { H. Walter } \\
& \text { Division of Environmental } \\
& \text { Control Technology } \\
& \text { Department of Energy } \\
& \text { Washington, DC } 20545 \\
& \text { Dave Watson } \\
& \text { Office of Pipeline Safety } \\
& \text { Regulation } \\
& \text { Department of Transportation } \\
& \text { 2100 Second St. S.W. } \\
& \text { Washington, DC } 20590 \\
& \text { Dan Wedderburn } \\
& \text { Office of Special Projects } \\
& \text { Office of Policy and } \\
& \text { Evaluation } \\
& \text { Department of Energy } \\
& \text { FED } 5302 \\
& \text { Washington, DC } 20024 \\
& \text { Lauren Weilburg } \\
& \text { Transportation Institute } \\
& 923 \text { I5th Street, N.W. } \\
& \text { Washington, DC 20005 } \\
& \text { Barry Yaffe } \\
& \text { Emergency Task Force } \\
& \text { Federal Energy Admin. } \\
& \text { l2th St. and Pennsylvania } \\
& \text { Ave. N.W. } \\
& \text { Washington, DC 20461 }
\end{aligned}
$$

\section{ONSITE}

6 DOE Richland Operations
W. A. Burns
J. C. Cummings
J. M. Peterson
H. E. Ransom
D. J. Squires

$$
\begin{aligned}
& \text { Washington Public Power } \\
& \text { Supply System } \\
& \text { G. Bailey }
\end{aligned}
$$

No. of

Copies

41 Pacific Northwest Laboratory

W. J. Bair

J. A. Bamberger

D. B. Cear lock

G. W. Dawson

J. G. DeSteese (10)

H. K. Elder

D. W. Fraley

A. L. Franklin

C. A. Geffen

R. J. Hall

P. L. Hendrickson

R. C. Liikala

J. W. Litchfield

W. V. Loscutoff

R. E. Rhoads

K. B. Sebelien

W. Wakamiya

L. D. Williams

C. L. Wilson

G. H. Winsor

Technical Information (5)

Publishing Coordination (2)

Water and Land Resources

Library

(5)

Ro

Battelle-Seattle 


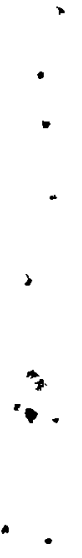

